\title{
Armoured test of Early Devonian Mesoconularia (Conulariida) from the Prague Basin (Czech Republic): probable adaptation to increased predation pressure
}

\author{
MICHAL MERGL, LENKA FERROVÁ \& JIŘí FRÝDA
}

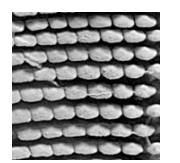

\begin{abstract}
An unusually complex type of skeletal ornamentation in the new conulariid species, Mesoconularia (?) lukesi sp. nov. from upper Emsian strata of the Prague Basin (Czech Republic) is described. The complex structure of elevated and heavily mineralized tubercles arrayed in transverse rows on the outer surface of the test of this conulariid is interpreted as a protective structure which probably evolved in response to increasing durophagy in the early Devonian. Favourable preservation of $M$. (?) lukesi sp. nov. revealed several hitherto unknown morphological features which could be important for reconstruction of the organisation and growth of the conulariid test. Polygonal imprints observed on the inner surface of the test laminae may represent epidermal cell moulds. The mineral component of the test of M. (?) lukesi consists of of carbonate-fluorapatite (francolite) and exhibits a homogeneous microstructure in both the outer and the inner layers of the test. - Key words: conulariids, Middle Devonian, biomineralization, microstructure, Barrandian.
\end{abstract}

Mergl, M., FerrovÁ, L. \& FrÝdA, J. 2016. Armoured test of Early Devonian Mesoconularia (Conulariida) from the Prague Basin (Czech Republic): probable adaptation to increased predation pressure. Bulletin of Geosciences 91(3), 561-581 (10 figures). Czech Geological Survey, Prague. ISSN 1214-1119. Manuscript received December 27, 2015; accepted in revised form October 13, 2016; published online November 15, 2016; issued November 25, 2016.

\begin{abstract}
Michal Mergl, Faculty of Environmental Sciences, CULS, 16521 Prague 6, Czech Republic; Argyrotheca@ seznam.cz• Lenka Ferrová, Institute of Geology and Paleontology, Charles University in Prague, Albertov 6, 12843 Prague 2, and Czech Geological Survey, P.O.B. 85, 11821 Prague 1, Czech Republic • Jiří Frýda, Faculty of Environmental Sciences, Czech University of Life Sciences Prague, Kamýcká 129, 16521 Praha 6 - Suchdol, and Czech Geological Survey, P.O.B. 85, 11821 Prague 1, Czech Republic; bellerophon@seznam.cz.
\end{abstract}

Conulariids are a group of Ediacaran (Van Iten et al. 2014a, b) to Triassic marine animals, in most species with a four-sided, steeply pyramidal mineralized theca $(=$ the test or periderm of various authors). They are generally classified as scyphozoans most closely related to extant coronates or staurozoans (e.g. Kiderlen 1937; Werner 1966a, b, 1967, 1970; Van Iten 1991; Jerre 1994; Hughes et al. 2000; Van Iten et al. 2006a-c, 2008, 2014b; Leme et al. 2008a) although other interpretations have been proposed (Termier \& Termier 1953, Kozłowski 1968, Bischoff 1973, Babcock \& Feldmann 1986a, Feldmann \& Babcock 1986, Babcock 1991). The microstructure and growth of the conulariid test have been investigated by a number of authors in recent years (e.g. Van Iten et al. 2005, 2006a, b; John et al. 2010; Ford 2011; Robson \& Young 2013; Ford et al. 2016), but the first studies are of a much earlier date. Bouček \& Ulrich (1929) presented the first study of the microstructure of conulariid tests. They were later followed by other authors, who demonstrated that the conulariid test is built of microscopic, phosphatic or chitinophosphatic lamellae paralleling the surface of the theca (Moore \& Harrington 1956, Kozłowski 1968, Bischoff 1978).
Transmitted light and scanning electron investigations supported earlier observations of the bilayered or multilayered structure of the conulariid theca (Van Iten 1992a, b; John et al. 2010; Ford 2011; Ford et al. 2016). The ultrastructure of the periderm consists of alternating phosphatic and organic microlamellae penetrated by thin phosphatic columns (Ford et al. 2016). On the other hand, suggested presence of fine canals piercing the base and summit of tubercles (Kozłowski 1968), and the presence of fine circular pores and pits in the lamellar microstructure of many conulariids (Van Iten et al. 2005, 2006b), contributed to discussions concerning the phylogenetic affinities of conulariids.

The bilayered structure and tetramerous symmetry of the conulariid theca have been interpreted as shared features of conulariids and coronatid scyphozoans (Werner 1966a, b, 1967). Werner (1966b) further noted that the bilayered organic theca of coronate scyphozoans is homologous to the basal and ornamentary layers of the conulariid theca. Van Iten (1992b) listed several particular similarities between the coronatid theca and the conulariid test and interpreted the mechanism of growth of the conulariid theca as involving centripetal deposition of non-ornamented lamellae on the 
inner surface of the theca. He noted that the hypothesis that the conulariid test is homologous to the theca of coronatid scyphozoans is based on similarities in microstructure and growth.

Bischoff (1973) described phosphatic, spike-bearing bars and plate-like elements as conodont-bearing substrates in the test structure of conulariids. He suggested that these structures are fragments of conulariid tests and reconstructed the conulariid animal with a thin periderm and simple-cone conodonts attached to tubercles resting on the transverse ribs. He postulated further that the ribs and spines constituted a complex food-trapping device. Although his suggestion is likely erroneous, Bischoff presented evidence of high morphological disparity in tubercle shapes on the faces of certain Ordovician and Silurian conulariids. Other fine structures of conulariid tests were observed by Jerre (1988, 1994). Rods and plates of Ctenoconularia sampled in the Lower Visby Formation (Silurian) of the Gotland show remarkable complexity of the conulariid micro-ornament. These data indicate that the external ornament of conulariid test (= periderm: John et al. 2010, Ford et al. 2016) is more complex than was suggested by some earlier authors.

In the present paper new conulariid specimens from Emsian strata of the Prague Basin are discussed. Our data indicate that some external structures of the conulariid test, especially the tubercles (= nodes by Simões et al. 2003), possess a complex morphology. Analysis of the phosphatic test of Mesoconularia (?) lukesi sp. nov. revealed several hitherto unknown morphological features which could be important for reconstruction of conulariid body organisation and therefore for interpretation of the phylogenetic affinities of the conulariid clade.

The complex structure of examined fragments of three Devonian conulariids has prompted us to evaluate certain hypothes concerning the origin and function of these structures. Reinforcement of the outermost mineralized layer of the tubercles by a heavily mineralized phosphatic cusp is interpreted as a form of protection against increasing durophagy.

We are aware that some of our conclusions may appear to be inadequately founded or controversial, or have been proposed previously by experts on conulariids in other contexts. We admit that our conclusions are inspired by structures observed in shells of organophosphatic brachiopods.

\section{Geological setting}

Described conulariids were collected from two lithostratigraphic units: the mid-Emsian Chýnice Limestone and the upper Emsian Suchomasty Limestone. The Chýnice Limestone Member of the Zlichov Formation (midEmsian; Chlupáč 1981) is a regional lithostratigraphic unit developed only in the Holyně-Hostim syncline and in the anticline of Doutnáč and Boubová of the Prague Basin (Fig. 1). The member records sea level changes during the so-called Daleje Event (Chlupáč \& Kukal 1988). The lithological characteristics of the member are rather variable, due mainly to changes in the ratio of coarse-grained bioclastic (mostly crinoidal) to finer bioclastic or micritic components. The colour varies from rosy to dark red brown, depending on the content of iron oxides (Svoboda \& Prantl 1948, Chlupáč et al. 1979, Ferrová et al. 2012). Its thickness reaches up to $15 \mathrm{~m}$. The Chýnice Limestone differs in colour and fauna from the underlying, grey micritic, offshore Zlíchov Limestone, which represents the lower and, in some places, the middle part of the Emsian in the Prague Basin. The Chýnice Limestone spans the N. barrandei and $N$. elegans biozones including the $N$. barrandei-elegans Subzone (see Ferrová et al. 2012). A deepening of the basin, with onset of deposition of the more offshore Daleje Shale, follow deposition of the Chýnice Limestone. The Chýnice Limestone is famous for its rich benthic fauna of corals, trilobites, gastropods, cephalopods, smooth-shelled brachiopods, crinoids and many other benthic invertebrates that originally formed small biostromes. The Čerinka locality is the most important fossil locality in the Chýnice Limestone. The fauna collected there was summarized by Chlupáč (1957), Chlupáč et al. (1979, 1998), Kovanda et al. (1984), and Havlíček \& Vaněk (1996). During the last two decades several new studies focusing on brachiopods (Mergl \& Ferrová 2009) and gastropods (Frýda 2001; Frýda et al. 2008, 2009) were published. Ferrová (2010) and Ferrová et al. (2012), based on a bed by bed study of two sections at the classical Čeřinka locality and in the nearby Čerinka Quarry, described in detail the environmental changes across the Daleje Event and proposed a new mid-Emsian tentaculite biostratigraphy as well as a new boundary for the Dalejan (= "Upper Emsian").

The Suchomasty Limestone (upper Emsian) is the regional lithostratigraphic unit in the Koněprusy area situated southwest of Prague (Fig. 1). It disconformably covers the reefal Koněprusy Limestone of Pragian age (Chlupáč 1998) and was deposited following a late Pragian-early Emsian (Zlichovian) sedimentary break followed by emersion and erosion of the reef. The thickness of the Suchomasty Limestone reaches up to $30 \mathrm{~m}$. The beginning of the deposition of the Suchomasty Limestone falls within the Nowakia elegans Biozone but already above the $N$. barrandei-elegans Subzone (see Ferrová et al. 2012). The Suchomasty Limestone sequence is dominated by well-bedded, reddish and grey biomicritic and biosparitic, predominantly crinoidal limestones, indicating a shallow-water and high-energy environment (Havlíček \& Kukal 1990, Chlupáč 1998). The tentaculite fauna includes the Nowakia elegans, N. cancellata, $N$. richteri and $N$. holynensis biozones (Chlupáč et al. 1979, 1986; Berkyová 2004; Ferrová et al. 2012). An upper 


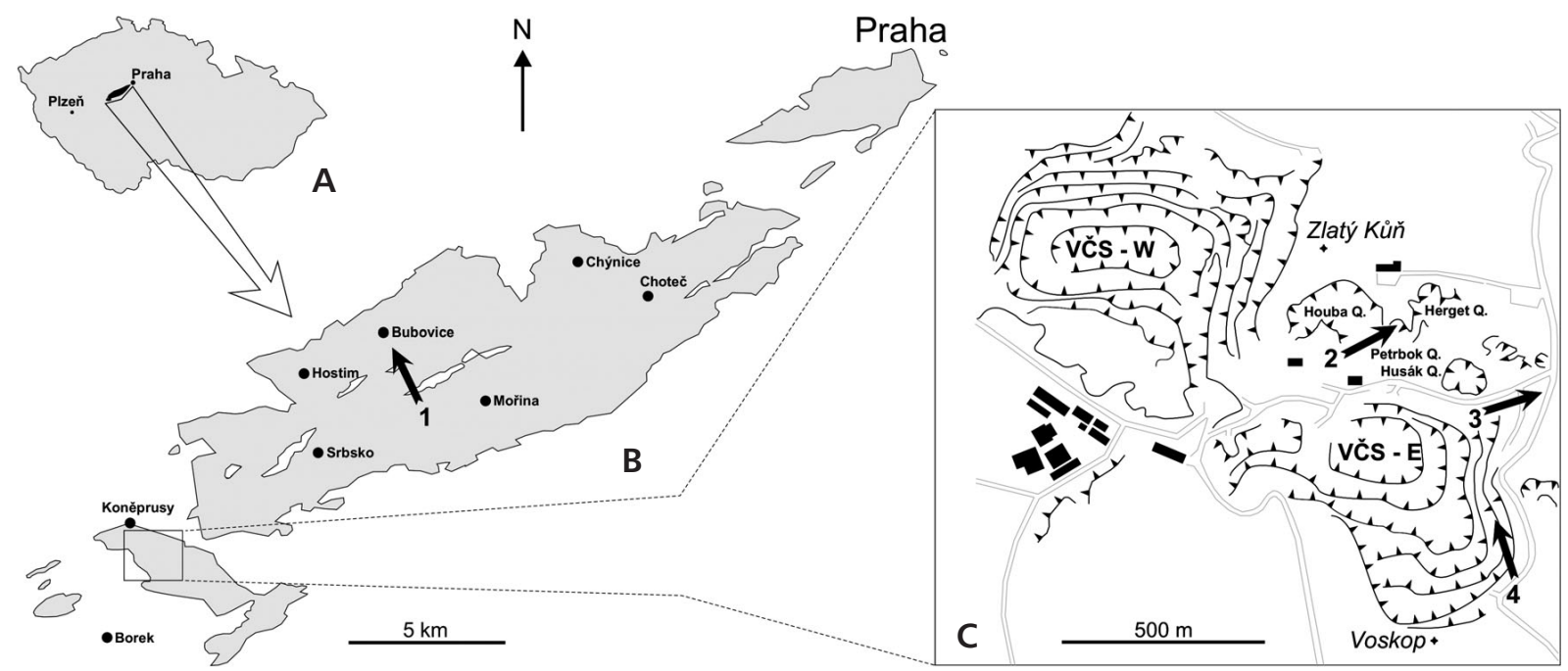

Figure 1. Schematic map showing Devonian of the Prague Basin in the Czech Republic (A), distribution of the Devonian in the Prague Basin (B) and localities in the Koněprusy area (C). Localities are marked by arrows. Modified after Mergl \& Ferrová (2009).

Emsian age is indicated by the presence of the Polygnathus laticostatus, $P$. serotinus and P. costatus partitus biozones (Klapper 1977, Klapper et al. 1978, Chlupáč et al. 1986, Chlupáč 1998, Berkyová 2009). The Suchomasty Limestone fills many subvertical neptunian dykes, which penetrate the older limestones (= Kotýs and Koněprusy limestones). The dykes follow an east-west strike. Their fillings were polyphasic (as indicated by their diverse lithology and fossil content). The neptunian dykes, discovered by Kukla (1952) and later described in detail by Chlupáč $(1955,1996)$, are an important source of fossils, namely trilobites and brachiopods. Conulariid tests here described were collected mostly from the neptunian dyke on Voskop hill near Koněprusy, but several fragments of the same conulariid species were also found at other localities.

\section{Localities}

Locality 1: Čeřinka ridge near Bubovice, a trench on the southeastern margin of a small depression (= "Čeřinka hillside" section by Ferrová et al. 2012); pink to red Chýnice Limestone with an abundant fauna of corals, crinoids and other fossils. Material studied comes from the tentaculite Nowakia barrandei-elegans Subzone of the N. elegans Biozone of Ferrová et al. (2012).

Locality 2: Petrbok Quarry; red biomicritic crinoidal limestone forming the lower part of the Suchomasty Limestone in the wall of the Petrbok Quarry, near Site No. 30 of Chlupáč (1996), with a rare and small brachiopod fauna.

Locality 3: The north slope of "Na Voskopě" hill, red to grey biosparitic and crinoidal limestones in a temporary excavation belonging to the upper part of the Suchomasty Limestone (locality 12 of Havlíček \& Kukal 1990). There are no conodont data from the outcrops but but the presence of Nowakia elegans and the absence N. barrandei (Frýda 1992) suggest that the limestone sequence belongs to the $N$. elegans Biozone.

Locality 4: East part of the quarry situated on "Na Voskopě" hill, a neptunian dyke filled by rose and red biosparitic limestones in the east wall of the quarry (locality 13 of Havlíček \& Kukal 1990). Sample comes from the "Main Dyke" at sites 25 and 26 of Chlupáč (1996; figs 1, 11, 12). Conodonts indicate the lower part of the Polygnathus serotinus Zone. The occurrence of the tentaculite Nowakia cancellata as the oldest biostratigraphically significant faunal elements in the "Main Dyke" (unpublished data, JF) suggests that this dyke was filled later than the beginning of deposition of the Suchomasty Limestone in other parts of the Koněprusy area.

\section{Material and methods}

Apart from a few fragments, all described conulariid tests come from localities 1 (Čeřinka hillside: Mesoconularia sp., Conularia sp.) and 4 (neptunian dyke in quarry "Na Voskopě“: Mesoconularia (?) lukesi sp. nov.). Only a few conulariids were sampled by hammering. Their tests were broken inside the wall during splitting of the rock, and the outermost test surface remained embedded on the reverse side of the limestone. The largest specimens were coated with the synthetic acrylate resin, DentaCryL. Limestone was later completely removed by immersion in a $10 \%$ solution of acetic acid. A thin sheet of the phosphatic test attached to the resin mat exhibits clearly the external surface of the test (Fig. 3C, D), although some tubercles were exfoliated due to the brittleness of the phosphatic material. 


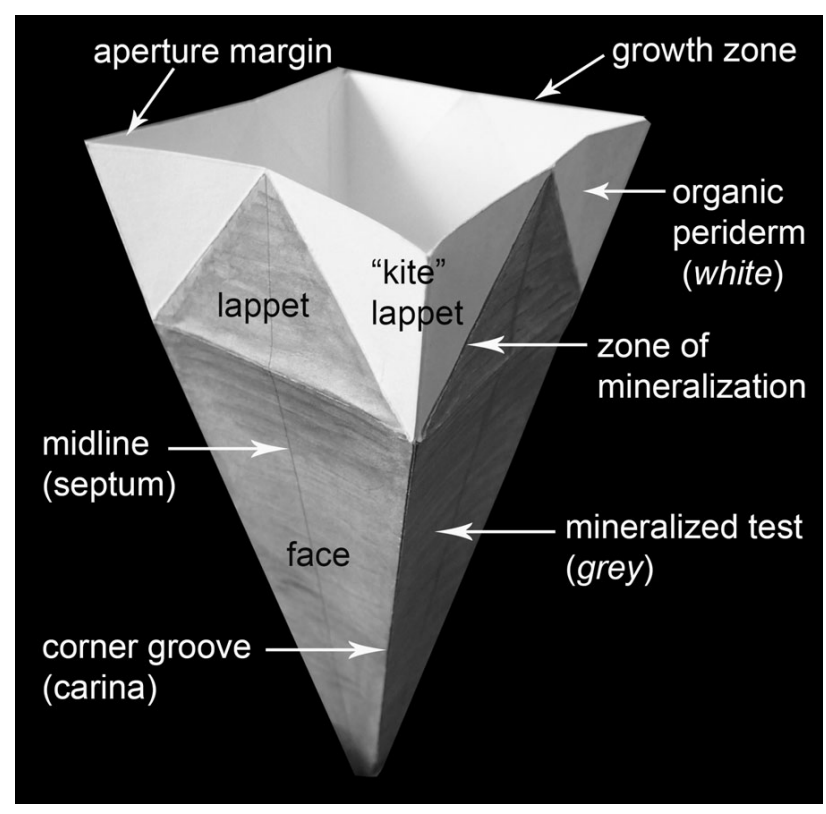

Figure 2. Conulariid thecal morphology, with the main terms applied.

Fragments of conulariid tests were yielded by dissolving of limestone. In total around $40 \mathrm{~kg}$ of the Chýnice Limestone and $100 \mathrm{~kg}$ of the Suchomasty Limestone were dissolved in acetic acid solution. Residues were repeatedly washed in still water and unsieved to avoid secondary fragmentation. About 40 determinable conulariid fragments and numerous isolated tubercles of four conulariid species were observed. Associated phosphatic fossils included conodonts, caudal spines of phyllocarid crustaceans, organophosphatic microbrachiopods, isolated dermal plates of microvertebrates, and Eurytholia sclerites (Mergl \& Ferrová 2009, Mergl \& Jiménez-Sánchez 2014).

Conulariid fragments were mounted on metal stubs, coated with gold and subsequently studied by SEM using JSM-6300 (Czech Academy of Sciences, České Budějovice) and by TESCAN (Czech Geological Survey, Prague). Large specimens (Fig. 3C, D) were coated with ammonium chloride and photographed using an OLYMPUS E-410 Camera equipped with a ZUYKO Digital $35 \mathrm{~mm}$ macro-objective.

Qualitative chemical analyses of fragments of Mesoconularia (?) lukesi test were performed by electron probe micro-analyzer Link Oxford Instruments (Czech Geological Survey, Prague). Other fragments of $M$. (?) lukesi test were separated for X-ray powder diffraction measurements under a binocular microscope and then gently pulverized together with ethanol in an agate mortar for about one minute. The resultant fine-grained powder was dried and instantly measured. The X-ray powder diffraction pattern was collected in the angular range of $10-80^{\circ} 2 \theta$ with a Bruker D8 Advance diffractometer (Czech Geological Survey, Prague) using CuK $\alpha$ radiation and a Lynx Exe XE detector. The X-ray powder diffraction pattern was evaluated using Diffrac EVA 2015 software, and apatite difractions from the angular range of $10-55^{\circ}$ were subsequently used for calculation of apatite lattice parameters using the refinement program, CELREF V3 (by Jean Laugier and Bernard Bochu, http://www.inpg.fr/LMGP).

\section{Repository}

All specimens, including the types of Mesoconularia (?) lukesi sp. nov. and other conulariids (Mesoconularia sp. and Conularia sp.), are housed in the palaeontological collections of the Centre of Biology, Earth and Environmental Sciences in the Faculty of Education of the University of West Bohemia in Plzeň (PCZCU).

\section{Terminology}

Terminology used in this paper is generally consistent with terminology used by Van Iten (1992b) and Van Iten et al. (2006b), but some terms for the description of tubercles are adopted from papers of Jerre (1988) and Simões et al. (2003). We use the term theca for the entire, organic and mineralized conulariid shell, but unlike John et al. (2010), the term periderm is used exclusively for the unpreserved external organic cover of the theca; the term test is used for mineralized parts of the theca. The term "kite lappets" is used for hypothesized, non-mineralized retractable parts of the theca (Fig. 2).

\section{Systematic palaeontology}

Phylum Cnidaria Verrill, 1865

Class Scyphozoa Götte, 1887

Order Conulariida Miller \& Gurley, 1896 emended Moore \& Harrington, 1956

\section{Genus Mesoconularia Bouček, 1939}

Type species. - Conularia fragilis Barrande, 1867; Pragian, Early Devonian; Koněprusy Limestone, Praha Formation; Bohemia.

\section{Mesoconularia (?) lukesi sp. nov.}

Figures 3, 4A-J, 5, 6

Holotype. - Test figured on Fig. 3A-D (PCZCU 2043).

Type horizon and locality. - Upper Emsian, Suchomasty Limestone of the Daleje/Třebotov Formation; "Main 
Dyke", a neptunian dyke situated in the eastern part of the "Na Voskopě" Quarry, south of Koněprusy.

Etymology. - After our colleague Pavel Lukeš and in honor of his crucial contribution to the Early Devonian tentaculite biostratigraphy of the Barrandian.

Diagnosis. - Mesoconularia with rows of robust subquadrate to transversally oblongish tubercles on the transverse ribs; ribs interlocking; tubercles deeply undercut adaperturally, with a heavily mineralized cusp; inner septum of midline thin but distinct.

Description. - Judging from available material, the test is narrowly pyramidal, $70 \mathrm{~mm}$ or so long. The test is gently curved with the apical angle measuring about $10^{\circ}$. The test wall is rather thin, being $c a 0.1 \mathrm{~mm}$ thick in the interspaces, but the thickness varies slightly depending on the location of the site of measurement.

The faces are subplanar to gently convex. Apertural lappets are unknown. The midline is externally distinct by a change in tubercle outline and by a change in curvature of the transverse ribs (Fig. 3D). Internally, the position of the midline is emphasized by a fine low septum that is gently raised above the internal face. The corner groove is shallow but distinct owing to a change in tubercle size and shape (Fig. 3C). The internal carina is very low but wider than the midline septum.

The transverse ribs are readily discernible only on the external surface, the internal surface of the test being almost planar. The transverse ribs are gently arched toward the aperture (Fig. 3A, B, E), exhibiting inflected circular curve geometry. The ribs disappear at the midlines and the corner grooves. The interspaces and transverse ribs form an interlocking contact along the midlines and corner grooves (Fig. 3C, D, E). The course of the ribs is marked on the internal surface of the test by transverse rows of low subelliptical nodes. These nodes are spaced evenly and correspond to the centres of the tubercles on the external face.

High tubercles are arrayed on transverse ribs (Fig. 3D). In general, tubercles on faces are oblong, subquadrate to squarish outlined, with thinner stalk-like bases (Fig. 3K, N), separated from each other by a very narrow gap (Fig. 3F, H). Tubercles are uniformly sized and shaped with a minor change of outline from transversally subrectangular at the centre of face to a less rectangular and more rounded outline toward the midlines and corners. Tubercles adjacent to the midlines and corners are differently shaped, with pointed cusps. They are separated by much wider gaps. The external surface of the tubercles is gently convex to pointed. The adapertural side of the tubercles is gently convex. The adapical side is extended, acute and overhangs the adjacent interspace (Fig. 3N). The interspaces are smooth and wider between the bases of the tubercles than between the external faces of the tubercles of the adjacent transverse rows of tubercles. The ornament is thus an almost continuous structure of tubercle cusps raised above the entire subplanar surface of the test face. The arrangement of the tubercles is very regular, with alternating position of tubercles in adjacent rows (Fig. 3D, H). There are 4 to 5 transverse ribs per $1 \mathrm{~mm}$. Depending on the location of the measured site, there are 3 tubercles (at the centre of the face) to 4 tubercles (on the margins of the face) per $1 \mathrm{~mm}$.

Tubercles near the midlines and corner grooves exhibit different sizes and shapes. The size of the tubercles gradually decreases toward the midlines and corner grooves (Fig. 3G). Their outline becomes less regular and their transverse width becomes shorter (Fig. 3K). The tubercles thus resemble squared mounds, cones or spines, having a narrower base and swollen or pointed cusps (Fig. 3I, J). The cusps of the cones and spines are gently inclined adapically (Fig. 3G). The gaps between the tubercles become larger concomitantly with changes in tubercle outline and shape (Fig. 3K, H).

The micro-ornament on the surface of the tubercles consists of sets of fine, oblique or subcentric wrinkles and subparallel fila (Figs 3M, N, 5A). Similar wrinkles and fila are present in the transverse and longitudinal interspaces and near the bases of the tubercles. The surface of the interspaces is obliquely but almost regularly deeply grooved near the midlines and corner grooves (Fig. 3G, I, L). Fine superficial pits are scattered over the surface of the interspaces. The pits are subcircular, deep, 3-4 $\mu \mathrm{m}$ in diameter.

The internal face of the test is smooth except for wavy and concentric lines corresponding to the growth edges of micro- or macrolamellae and for the transverse rows of low elliptical nodes.

Remarks. - The genus Mesoconularia is based on a poorly known and hitherto unrevised species, M. fragilis (Barrande, 1867) of early Devonian age (Koněprusy Limestone, Pragian). We do not solve this taxonomy of Mesoconularia problem herein. The new species is remarkable for its external ornamentation. However, despite some differences, the gross morphology of the new species is similar to that of Mesoconularia fragilis (Barrande, 1867). Therefore, we assign, with some doubts, the new species to the Mesoconularia Bouček, 1939. Mesoconularia (?) lukesi differs from $M$. fragilis in having larger and higher tubercles and finer and more densely spaced transverse ribs. Mesoconularia fragilis is a large species, with the length of its test being about $160 \mathrm{~mm}$. The actual size of adult specimens of $M$. (?) lukesi is unknown. The holotype of $M$. (?) lukesi is $50 \mathrm{~mm}$ long but represents only part of the test.

Barrande (1867) stated that Conularia fragilis (= M. fragilis) is very rare in his "bande $\mathrm{f} 2$ " in the 
Koněprusy area ("Konieprus" and "Mnienian" in his original spelling). However, the exact stratigraphical and locality data of these specimens are unknown, because Barrande's "bande f2" comprises the Koněprusy Limestone (Pragian), the Suchomasty Limestone (upper Emsian) and the Acanthopyge Limestone (Eifelian). Bouček (1928) noted that he had about 65 specimens from three different collections, including Barrande's collection stored in the National Museum in Prague. However, none of Bouček's (1928) figured specimens is the original of Barrande (1867). Specimens illustrated by Bouček (1928, pl. 5, figs 8,9) are not accessible at present because he did not specify their repository and inventory numbers. His note concerning the yellow colour of the limestone may indicate that both figured specimens came from the Koněprusy Limestone (Pragian). If this conclusion is true, then Bouček's specimens are of Pragian age and stratigraphically pre-date our specimens, which were collected from the upper Emsian Suchomasty Limestone.

The facts that a lectotype was not selected and the type specimens of Barrande (1867) are not available make somewhat unclear the affinity of the new species to the type specimens of Conularia fragilis Barrande, 1897. All specimens stored in the National Museum, Prague, which Bouček referred to C. fragilis (Bouček 1928, p. 33) belong to a single species. All specimens are preserved in white or yellowish limestone, which is almost certainly the Koněprusy Limestone. The specimens are similar to two specimens figured by Bouček (1928). The collection of the National Museum Prague contains no specimens from the Suchomasty Limestone. Therefore, we assume that all specimens of Conularia fragilis, including Barrande's types, were collected from the Koněprusy Limestone of the Pragian age.

Bouček's (1928, pl. 5, fig. 10) drawing of M. fragilis ornament displays fine "pores" caused by breakage of the tips of tubercles. The same feature was observed in our specimens. These small holes are artificial openings caused by splitting of the rock. The pore is an opening into a chamber inside the tubercle, which originated by closure of the cavity by the accretion of mineralized lamellae on inner surface of the test. Similar cavities were observed in other conulariids in our material from the Prague Basin.
Occurrence. - Upper Emsian, Suchomasty Limestone; Koněprusy, Zlatý Kůň and "Na Voskopě” hill.

\section{Mesoconularia (?) sp.}

Figure 4N, O

Material. - Two fragments; N. barrandei-N. elegans Subzone of the N. elegans Biozone, upper Emsian; Chýnice Limestone; Čeřinka hillside (locality 1) near Bubovice.

Description. - The gross test shape is unknown. The transverse ribs bear an array of closely spaced subrectangular tubercles. The outline of the tubercles is subquadrate to longitudinally oblongish, with a very narrow gap in between. The width of the tubercles is about $250 \mu \mathrm{m}$.

Remarks. - Fragments of transverse ribs with closely packed subrectangular tubercles are very similar to tuberculate ribs of Mesoconularia (?) lukesi sp. nov. The main difference is the outline of the tubercles. These are strictly subquadrate to longitudinally oblong in $M$. (?) sp. but generally transversely oblong in $M$. (?) lukesi. However, we consider this subtle difference to be important. In all conulariid fragments from the Suchomasty Limestone and referred to $M$. (?) lukesi, none of the tubercles is so elongately subquatrate; instead, they are much more rounded or transversely oblong (Figs 3F, H, K, 4A-C), unlike fragments from the Chýnice Limestone (Fig. 4N, O).

Occurrence. - Only locality 1.

\section{Genus Conularia Miller in Sowerby, 1821}

Type species. - Conularia quadrisulcata Sowerby, 1821; Namurian; Carboniferous, Millstone Grit Group; England.

Conularia (?) sp.

Figure 4K-M

Material. - Two test fragments likely derived from the same specimen (they were found in the same rock sample);

Figure 3. Mesoconularia (?) lukesi sp. nov., Suchomasty Limestone, Koněprusy, locality 3. • A, B - incomplete test, internal mould with exfoliated test and its exterior, PCZCU 2043. • C, D - exterior of the same test facing corner groove (C) and the face with midline (D), showing arrays of oblongate tubercles of face and smaller tubercles along the midline and corner groove, PCZCU 2043. • E - external mould showing midline, interlocking nature of ribs and rows of nodes corresponding to shafts of tubercles, PCZCU 2048. $\bullet \mathrm{F}, \mathrm{M}, \mathrm{N}$ - fragment of test, with rows of tubercles (F), external wrinkles on its surface (M) and wrinkles on interspaces (N), PCZCU 2038. $\bullet \mathrm{G}$ - fragment of test near the corner groove showing folding and gradual change of tubercle shape from subrectangular (left) to acutely pointed (right), PCZCU 2041. • I, J, L - fragment of test near the midline showing shape of tubercles (I) with undercut cusps (J), and minute pits on the extermost lamina of the inner layer (L), PCZCU 2042 . $\bullet H$ - fragment of test showing surface of interspaces and arrangement of tubercles in a superstructure, PCZCU 2039. $\bullet \mathrm{K}$ - fragment of the face with arrays of tubercles and gaps and interspaces in between, PCZCU 2040. Bars $=1000 \mu \mathrm{m}(\mathrm{A}-\mathrm{E}), 100 \mu \mathrm{m}(\mathrm{F}-\mathrm{K}, \mathrm{M}, \mathrm{N})$ and $10 \mu \mathrm{m}(\mathrm{L})$. 
Michal Mergl et al. • Armoured test of Early Devonian Mesoconularia (Conulariida) from the Prague Basin

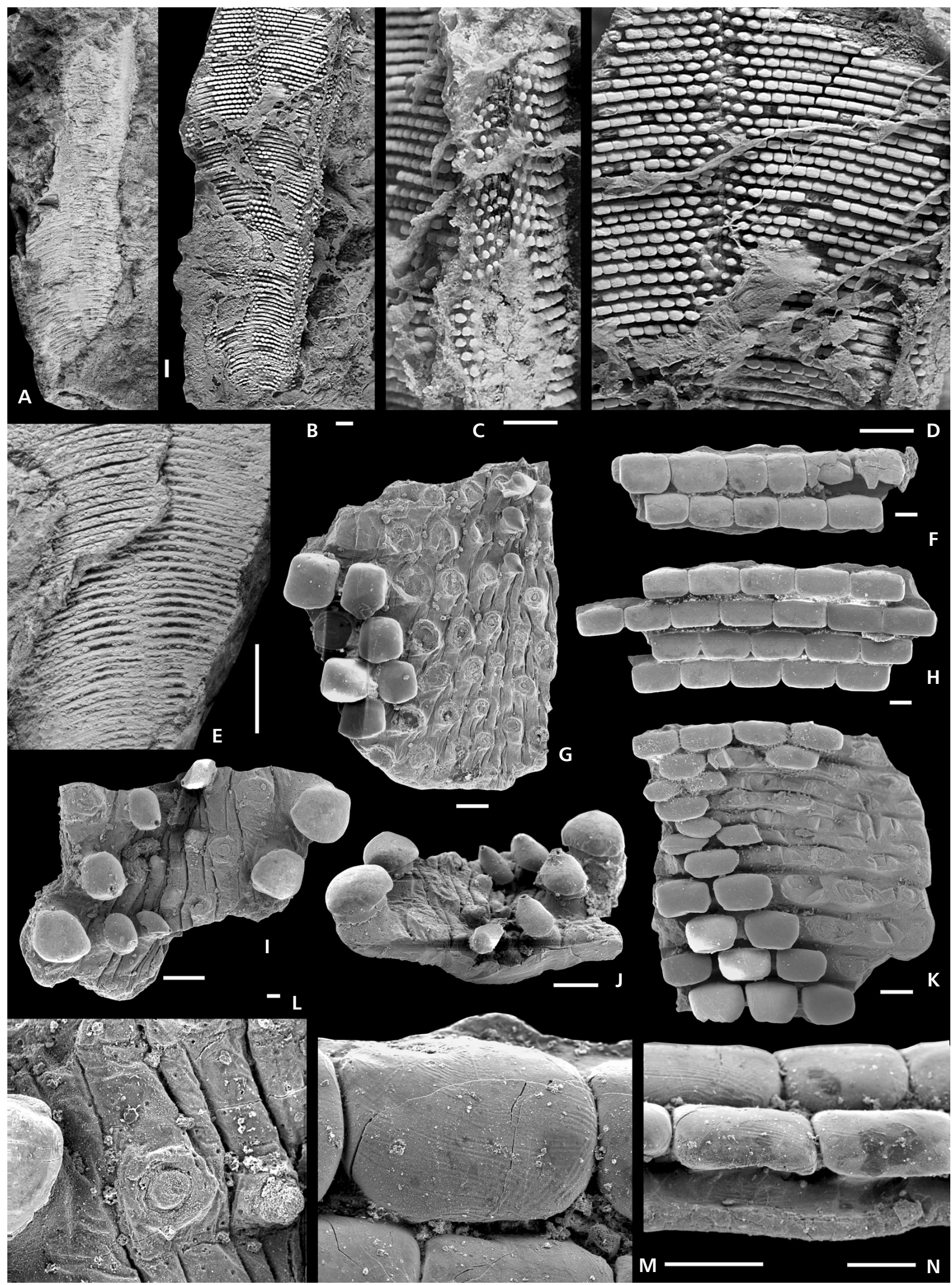


$N$. barrandei-N. elegans Subzone of the N. elegans Biozone, upper Emsian; Chýnice Limestone; Čeřinka hillside (locality 1) near Bubovice.

Description. - The general test shape is unknown. The test wall is thin, about $50 \mu \mathrm{m}$ thick in the interspaces. The thin and low transverse ribs are slightly elevated above the interspaces, which are about four times wider than the ribs. The ribs are moderately arched adaperturally and disappear near the corner groove. The crest of the ribs bears tubercles of uniform shape and size. The tubercles are arranged in distinct arrays with an almost uniform spacing of 100 to $150 \mu \mathrm{m}$. The tubercles have a short basal trunk oriented perpendicular to the ridge, having an acutely pointed and morphologically differentiated apex. The adapical side of the tubercle tip bears a flattened triangular area (Fig. 4M). The apex of some tubercles is penetrated by a small hole opening into the cavity inside the tubercle, but this hole is likely secondary because other tubercles show a pointed tip lacking the hole. The concentric lamellar structure is visible in broken tubercles. Tubercles in adjacent ribs alternate in position, forming distinct oblique rows on the test face. The corner groove exhibits a distinct, longitudinally and obliquely folded and furrowed surface, and the tubercles are relatively small and conical.

Remarks. - The fragments show well the complex morphology of the tubercles, with differentiated adapical and adapertural faces. The lack of information concerning the gross test morphology makes the taxonomic position of the fragments unclear. We refer the fragments to Conularia s.l., because most genera of Ediacaran to Devonian conulariids (Archaeoconularia, Baccaconularia, Glyptoconularia, Metaconularia, Paraconularia, Pseudoconularia) exhibit only low nodes or simple tubercles. To our knowledge no previously described conulariids exhibits such complex tubercle morphology. The ornament of Ctenoconularia is different, having comb-like interspace ridges (Jerre 1988, Van Iten et al. 2008).

Occurrence. - Only locality 1.

\section{Comments regarding the morphology of conulariid tests}

\section{Periderm}

The former presence of an outermost, non-mineralized organic layer (= periderm) in the conulariid test was first proposed by Van Iten (1992b), but can hardly be directly evidenced in the fossils record. It existence can be interpreted from growth abnormalities (Van Iten 1992b). The first-formed lamina of the mineralized layer of a conulariid test likely represents the cast on the inner side of the periderm (Van Iten 1992b, Ford et al. 2016). This conclusion is inspired by features of the organophosphatic brachiopod shells. The cast of the outer organic layer (= brachiopod periostracum) is formed by the external-most first-formed lamina of the mineralized shell. The complex structure of the inner side of the brachiopod periostracum cover is imprinted into the first-formed lamina of the mineralized shell in fascinating details including the outline and convexity of extracellular vesicles, various tablets, tensile linear folds and parallel sided drapes of the periostracal layer (Williams \& Mackay 1979, Williams \& Holmer 1992, Williams et al. 1998, Cusack et al. 1999, Williams \& Cusack 1999). Similar casting of inner surface of the periderm is suggested for the mineralized conulariid test.

The external surface of the mineralized tubercles of Mesoconularia (?) lukesi sp. nov. aligned in the transverse ribs is generally smooth, but some tubercles exhibit fine wrinkles grouped in distinct bundles or restricted to delineated places (Figs 3M, N, 5A). Fila and wrinkles may be subparallel to each another, often tracking the direction of the transverse ribs, but other, chevron-like or radial arrangements of the wrinkles are present on the same tubercle. Groups of wrinkles may be truncated by peripheral wrinkles of other delineated area (Fig. 3M), but one array of wrinkles may be superimposed on another array (Fig. 3M, right lower corner). Some of these low wrinkles are distinct on the margins of the tubercles. The length of the wrinkles varies. They are short but also may continue over the entire transverse width of the tubercle. Similar

Figure 4. Mesoconularia (?) lukesi sp. nov., Suchomasty Limestone, Koněprusy, locality 3. • A, E - fragment of test with exfoliated outer layer and the tubercle showing regularly spaced ectodermal cell moulds (E), PCZCU 2044. • B, D - fragment of test (B) and exfoliated outer layer (D), PCZCU 2045. • C - fragment of test with strongly elongate tubercles, PCZCU 2046 . $\bullet$ F - fragment of test with exfoliated outer layer showing irregularly shaped ectodermal cell moulds on surface of the externmost lamina of the inner layer, PCZCU 2079. • G - etched surface of transversely sectioned tubercle showing the thickness and overturning of the "cap" of the tubercle, PCZCU 2037. • H-J - fragment of test, inner surface showing elongate nodes with convex (I) and concave (J) tops and stepped edges of particular laminae of the inner layer, PCZCU 2047. • K-M - Conularia sp., Chýnice Limestone, Čeřinka locality. $\bullet \mathrm{K}$ - fragment of test showing transverse ribs with arrays of tubercles near the corner groove; note rheomorphic folding of surface in corner groove, PCZCU 2033. $\bullet$ L, M - fragment of test showing transverse four tubercles with triangular area on their adapical side, PCZCU 2034. • N, O - Mesoconularia (?) sp., Chýnice Limestone, Ceřinka locality. $\bullet \mathrm{N}-$ fragment of test showing subquadrate tubercles and narrow gaps, PCZCU 2035. $\bullet$ O - fragment of test showing two tubercles with exfoliated outer layer, PCZCU 2036. Bars = 100 $\mu$ m $(\mathrm{A}-\mathrm{C}, \mathrm{G}-\mathrm{O})$ and $10 \mu \mathrm{m}(\mathrm{D}-\mathrm{F})$. 


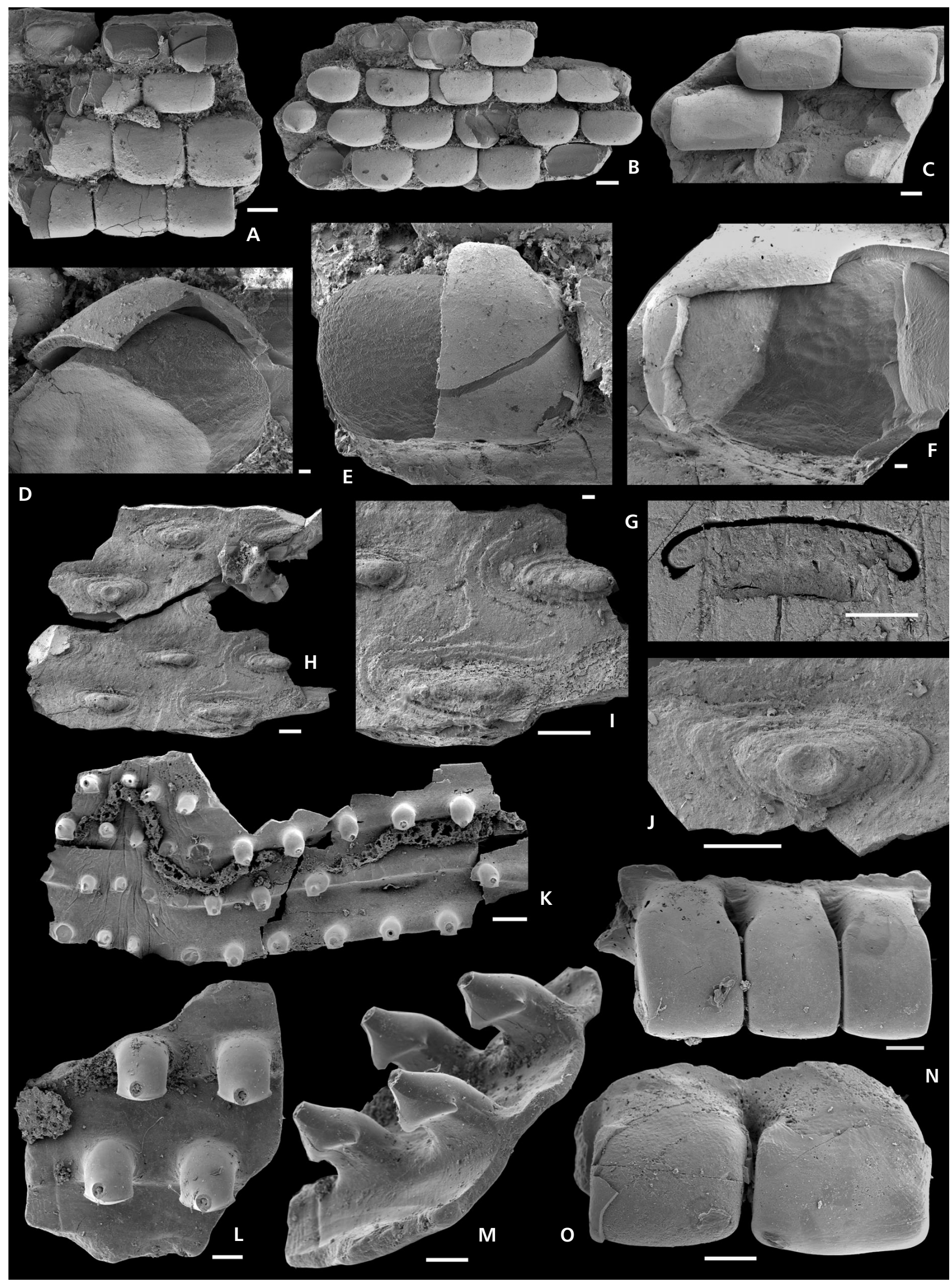


wrinkles and ridges are present on the interspaces and gaps between the tubercles (Fig. $3 \mathrm{~N}$ ).

We interpret the wrinkles as imprints of the inner surface of an exclusively organic periderm. The organic, non-mineralized periderm near the growth edge of the theca (Fig. 2) likely formed, apart from the relatively flat surface of the interspaces, also the transverse rows of external protuberances. The first mineralized lamella (Fig. 5F) was accreted onto the internal surface $(=$ chamber $)$ of a particular peridermal protuberance. Therefore, the preserved external surface of the mineralized tubercle should exhibit a negative imprint of the inner surface of the unpreserved peridermal protuberance. The organic periderm was likely thin but multilayered. It seems reasonable to suggest that the approximate thickness of the organic periderm may be inferred from the width of the gap separating adjacent tubercles on the transverse ridges. This gap is about $10 \mu \mathrm{m}$ wide. Since the periderm was bent between two tubercles then its thickness was less than $5 \mu \mathrm{m}$.

The thickness of the perisarc in the Recent colonial hydrozoans comes to mind in this context. Its thickness depends on age. The perisarc is thicker by deposition of material in inner side. The perisarc is thicker in the older parts of the colony, but the distal perisarc near the aperture is only 3-4 $\mu$ m thick (Hughes 1992, Kossevith 2001).

We suggest that sets of wrinkles on tubercle faces represent traces of accretion of a thin organic periderm at the apertural margin of the conulariid test. Crossed wrinkles likely represent traces of accretion of the new layer superimposed onto the older layer. Wrinkles on the sides and stalks of the tubercles may represent deformation structures of the somewhat flexible organic periderm or already mineralized but very thin and flexible first mineralized lamellae. The heavily mineralized cusp of tubercle resting on the heretofore unmineralized or weakly mineralized stalk of the organic periderm could explain such deformation of the stalk. There are no signs of reticulate ornament, which may represent ectodermal cell imprints.

Different structure on the first-formed mineralized lamella or lamellae is developed near the midlines and corner grooves. Here are folds and deep subparallel grooves (Fig. 3G, I, L) and the surface resembles the superficial structures known in some organophosphatic brachiopod shells (see Williams \& Holmer 1992, Williams 1997). The surface of the interspaces and gaps between the tubercles near the lateral ends of the ribs and at the bottom of the corner groove are deeply plicated by oblique, narrow, and irregularly meandering grooves (Fig. 3G). These oblique grooves converge either toward the midline or toward the corner groove. The grooves never cut the bases of the tubercle (Fig. 3G, I, L). The grooves embrace tubercles leaving a sheltered surface behind them (in adapical direction). We propose that the tubercles were the first mineralized and therefore the toughest objects in the surrounding to date flexible and non-mineralized periderm. The organic periderm softly folded along the tubercles in this stage of growth of Mesoconularia (?) lukesi. Subsequently, these folds and wrinkles were casted into the first-formed lamellae of the mineralized test. The stronger development of the folds along the midline and the corner groove indicates that these parts of Mesoconularia (?) lukesi, and, possibly in conularid in general, represent mechanically more deformed zones compared with the flat surface of the faces. The midline is a smoothly curved part of the shell (Ford et al. 2016). The corner groove likely formed a more rigid zone than the faces. The almost $180^{\circ}$ inward bending (Fig. 9A) of the prevalently organic "kite" lappets (Fig. 2) in the closed conulariid produced many small pressure and/or tension-induced induced plications and folds of the periderm along the zone of bending (Figs 3I, J, 9A2, B2). It is worth pointing out that the width of the grooves is approximately $10 \mu \mathrm{m}$. This width roughly corresponds to the suggested thickness of organic periderm in the gaps between the tubercles on transverse ribs.

\section{Tubercles}

The heavily mineralized cusp is distinctly developed only on the tubercles (Figs 4D, 5E, 6C). The cusp forms a "cap" preserved by a glassy phosphate, different from the opaque material of the interspaces, the "stalk" of the tubercles, and the test in the underside of tubercles. The periphery of the cap is deeply undercut (Figs 4G, 5D). This is obvious on the "stalk" of the tubercles (Figs 3J, 5B). The similar discontinuity of several macrolaminae that are discontinuous laterally and form the top of the tubercle is visible also in Paraconularia sp. (Ford et al. 2016, figs 5:5, 6) but unlike them we do not interpred this discontinuity as breakage artifact. The thickness of the glassy cap is about $15-20 \mu \mathrm{m}$ (Figs 4D, G, 5E, 6). There is a poorly visible lamination inside the cap (Fig. 6C). It seems that the cap of Mesoconularia (?) lukesi sp. nov. was rather homogeneous, heavy mineralized, and composed of at most three to four thick macrolamellae (Fig. 6C). The strongly concave inner side of the "cap" is visible as a distinct discontinuity (Fig. 6C) within the tubercle. This concavity we interpret as the first distinct non-mineralized, therefore the organic macrolamella (Fig. 6C). This discontinuity commonly caused desquamation of the cap from the subjacent mineralized lamina (Figs 4D, 5E). A similar discontinuity was figured in the test of Metaconularia by John et al. (2010, fig. 8:1). The discontinuity is likely the result of accretion of a weakly mineralized (?organic) layer separating more mineralized macrolamellae from each other ( $c f$. Ford et al. 2016). The amount of suggested organic substance in the test wall is shown in Fig. 6. The massively mineralized caps are 


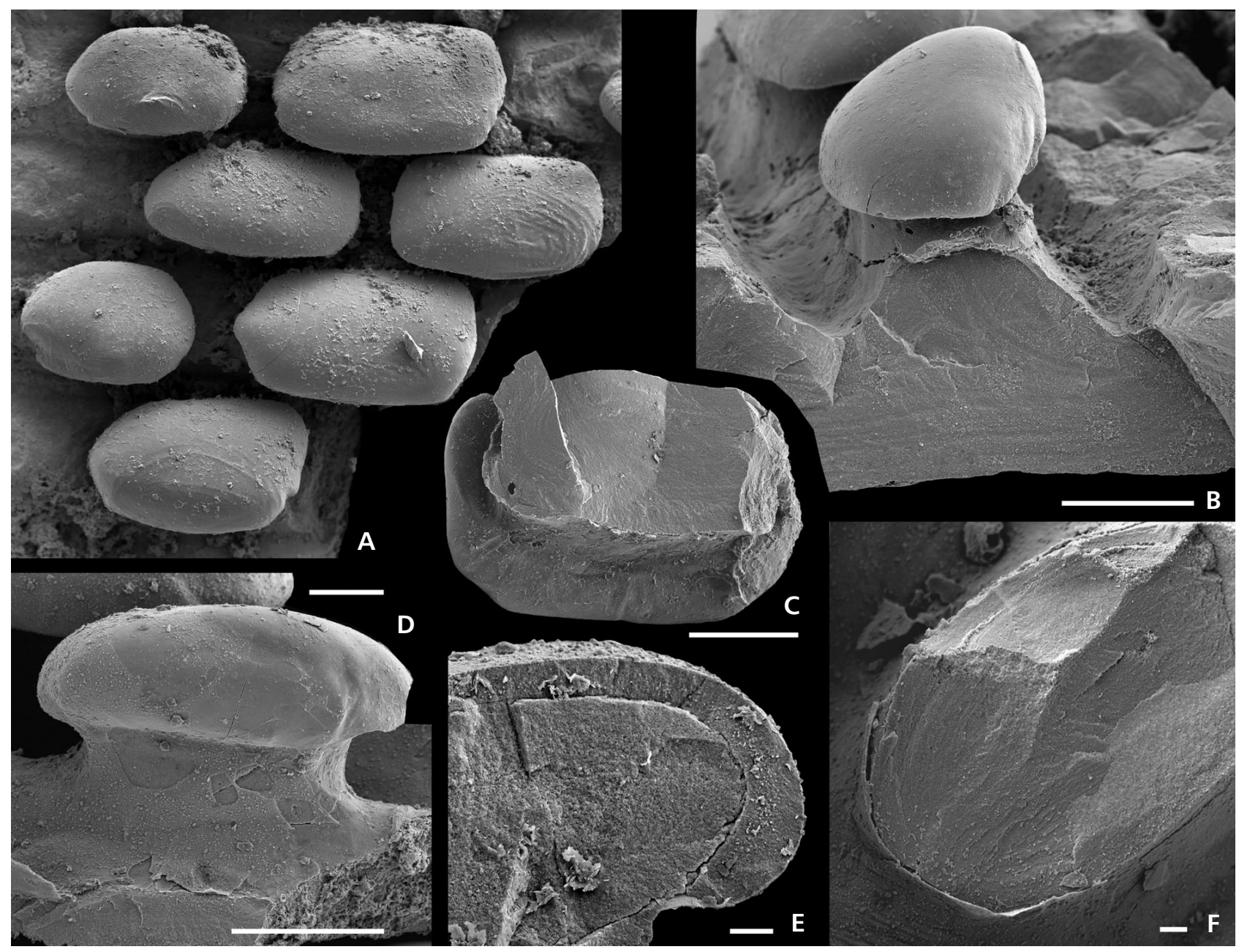

Figure 5. Mesoconularia (?) lukesi sp. nov., Suchomasty Limestone, Koněprusy, locality 3. • A, B, D - fragment of the test with wrinkles on surface of tubercles (A), side view showing the first formed cap and lamination of inner layer (B), and (D) side view to tubercle showing surface of the first-formed layer (polygonal spots are imprints of calcite crystals of limestone matrix), PCZCU 2050. $\bullet$ - cross-section by a tubercle showing concentric structure of its stalk. $\bullet \mathrm{E}$ - broken tubercle with distinct boundary between outer and inner layers; note sharp truncation of the "cap" and preserved a very thin externmost layer preserved there. $\bullet \mathrm{F}$ - cross section by base of tubercle; note the thin, partly exfoliated externmost layer that form continuos layer on "caps" and "stalks" of the tubercle and adjacent interspaces. Specimens C, E, F were destroyed in SEM investigation. Bars = $100 \mu \mathrm{m}(\mathrm{A}-\mathrm{D})$ and $10 \mu \mathrm{m}(\mathrm{E}, \mathrm{F})$.

bright, lacking distinct brown lamination. Thinner lamination and higher amounts of organic substance within the interspaces, the "stalk" of the tubercles, and on the undersides of the tubercles are shown by brown coloration caused by thermal degradation of original organic matter.

\section{Inner surface of the test}

The test wall (= mineralized periderm; Ford et al. 2016$)$ of Mesoconularia (?) lukesi sp. nov. is built of a finely and distinctly laminated substance. The lamination is distinct in thin sections and it is also evident on the internal surface of the test (Fig. 4H, I). The inner subplanar surface of the test bears regularly spaced, transversely elliptical to subel- liptical nodes (Fig. 4H). These are gently elevated above the adjacent subplanar surface. The nodes show conspicuous concentric growth zones, with a knob-like body having an elevated, or rarely, depressed centre. Growth laminae are visible as stepped and meandering lines on the internal surface of the test between the nodes (Fig. 4I). Topographically, the nodes are an internal extension of the tubercle bases resting on the external transverse ribs. This is evident from the spatial distribution of nodes forming regular transverse rows (Fig. 3E, 4H), but the nodes also alternate in the adjoining rows in the same way as the external tubercles.

We assume that the nodes represent zones of greater production of mineral substance by gland cells of the ectoderm. The ectoderm adjacent to the interspaces and 

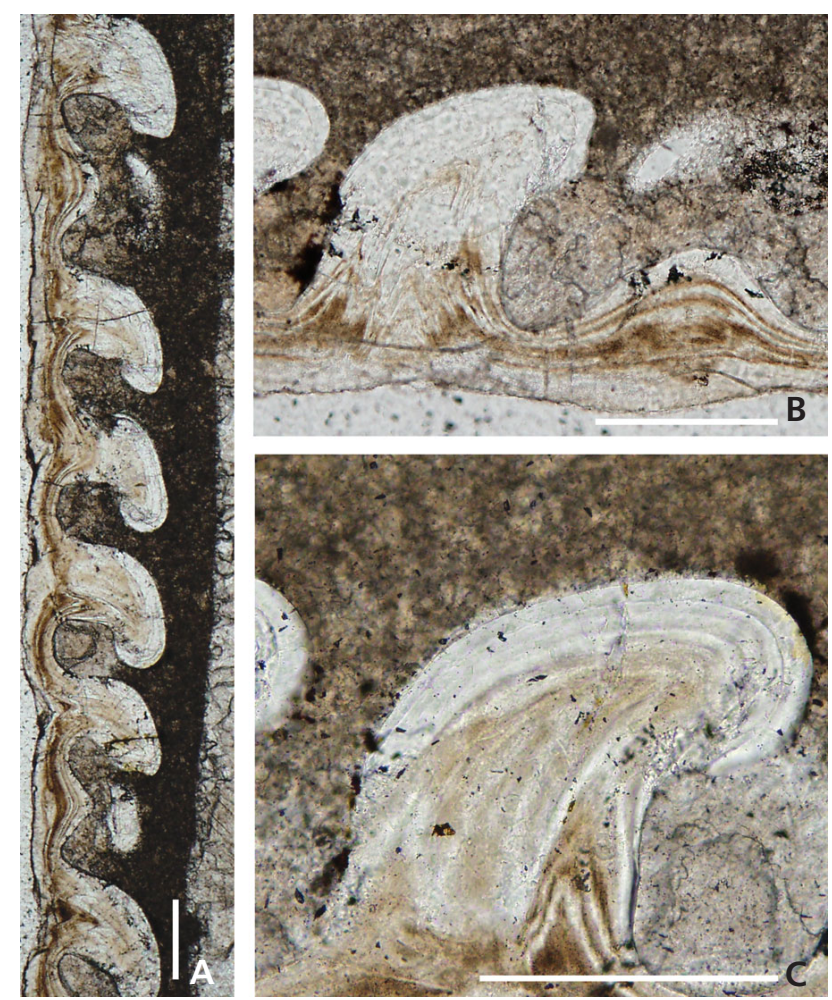

Figure 6. Mesoconularia (?) lukesi sp. nov. • A-C - thin elongate section of the test; Suchomasty Limestone, Koněprusy, locality 3, specimen PCZCU 2049. • A - section of several ribs showing adapically overturned tubercles. $\cdot \mathrm{B}$ - section of tubercle with internally layered structure and brow-coloured, originally likely organic substance in inner layer; note mound-like profile of rib and concave surface of laminae in ribs. $\bullet \mathrm{C}-$ tubercle with distinct transparent phosphate cusp with undercut corners, separated from the lamina of the inner layer by a distict line (indicated by arrow). Bars $=100 \mu \mathrm{m}$.

gaps between the nodes produced comparatively less phosphate. The accretion of early phosphatic lamellae copied the shape of the pouch-, mound-, cone- or thorn-like external protuberances formed by the organic periderm. As shown in thin sections, the earliest lamina of the first-formed, fully continuous mineralized lamella was accreted to the concave surface of the tubercle cap, on the sides of the tubercles and in the interspaces. Subsequently, accreted laminae began to fill the cavity and finally closed the internal opening, sometimes leaving an empty chamber inside the tubercle (Fig. 7). The consecutive accretion of the mineralized laminae is evident from the annuli of the tubercles in cross sections (Fig. 5C, F).

\section{Margins of the apertural lappets}

Apertural lappets are unknown in Mesoconularia (?) lukesi sp. nov. specimens. We suggest that closure of the theca of Mesoconularia (?) lukesi was similar to the lobate lappet type of closure exhibited by a specimen of Conularia brongiarthi Archiac \& Verneuil, 1842 (Sendino et al. 2011, figs 3C, 4) and in Conularia sp. from the Hunnsrück Slate of Germany (Van Iten \& Südkamp 2010). This assumption is based on the similar shape of the transverse ribs of Conularia brongiarthi, C. sp. and Mesoconularia (?) lukesi. Even with maximum closure there were still substantial gaps between the margins of the lappets.

Some of the features observed in Mesoconularia (?) lukesi, for example variation in tubercle shape within transverse ribs in particular face and interlocking alternation of transverse ribs along corner grooves (Fig. 3C-E) can be interpreted as the adaptation to soft interlocking closure of small apertural "kite-shaped elements" located between shortly triangular and already mineralized lappets (Figs 2, 8). We follow the suggestion of Sendino et al. (2011) that there was an organic sheet between the mineralized lappets (Fig. 2). However, there are at least two alternatives concerning the presence of mineralized apertural lappets.

The first alternative suggests that the lappets were present only in mature specimens, when growth of the theca along the apertural end was terminated and mineralization of the test continued only in the gradually tapering triangular face of the lappets. Consequently, closure of the aperture was possible only in adult specimens closer to the end of the life of the conulariid individual.

The second alternative suggests that lappets were present, at least, for a longer life span of the conulariid (Bouček \& Ulrich 1929). If we follow this second alternative, there are consequences relevant to the mineralization of the transverse ribs. In general, the ribs are not parallel with the sides of a lappet (Sendino et al. 2011, figs 3, 4). We must assume that the first mineralized tubercles on the transverse ribs originated close to the midline, because he midline forms the growing point of the lappet. Particular tubercles in their arrays were progressively mineralized toward the corners (Fig. 8). At the beginning of mineralization of the shell, the small-mineralized centres of tubercles were surrounded by flexible organic periderm. The flexible organic periderm could easily bend inward along the aperture (Fig. 9A1-A5). Plicated type closure with a "kite-like" outline and figured in Metaconularia (?) anomala by Bouček (1928) and Sendino et al. (2011, figs 1 and 3A), likely represents a similar inwardly folded, organic or weakly mineralized periderm ("kite" lappets) lacking mineralized tubercles and ribs. Mineralized ribs are preserved on the triangular face of apertural lappets and on the faces. Deformation of the periderm near the corners of the test was subsequently imprinted as folds and plications in the first mineralized layer as the mineralization progressed toward the corners. The small tubercles at the ends of the transverse ribs near the margins of adjacent lappets are interlocking (Fig. 3C, D). We suggest that the eventual contact of faces formed tough closure of the lappets and/or this 
interlocking represents an adaptation inhibiting direct contact of mineralized tubercles and/or corresponding glands cells, respectively, along the margins of the adjacent inwardly folded lappets. The similarly shaped casts of gently folded periderm are present on surface of first-formed mineralized lamellae along the midline. The midline was able to fold as seen in some described conulariid specimens (e.g. Babcock et al. 1987, Sendino et al. 2011, Ford et al. 2016).

\section{Pits}

The small hemispherical pits are irregularly dispersed on the surface of the first-formed mineralized lamella the interspaces and along the midlines and corner grooves (Fig. 3L) of M. (?) lukesi. The pits are almost uniformly sized, with a diameter of up to $3 \mu \mathrm{m}$. The pits do not continue into the canals penetrating the wall or, at least, some lamellae of the test. The inner surface of the test exhibits no structures similar to pore openings.

The pits likely are not homologous to the microscopic circular pores described by Kozłowski (1968) and Van Iten et al. (2005, 2006b), despite the similar diameter of the pores. Van Iten et al. (2005) claimed that pores in many post-Cambrian conulariids are $2 \mu \mathrm{m}$ to $12 \mu \mathrm{m}$ in diameter, and layers with pores may be separated by layers without pores. The similar circular pores, with diameter $5 \mu \mathrm{m}$ to $15 \mu \mathrm{m}$ are known in the Furongian Baccaconularia (Van Iten et al. 2006b). The authors proposed three hypotheses of their origin. They may be external openings of microscopic pores, traces of microborings or an endosymbiotic organism in bioclaustrations (Van Iten et al. 2006b). Pores were not observed in Mesoconularia (?) lukesi sp. nov. We interpret these pits as the imprints of the extracellular vesicles trapped on the underside of the layer of organic periderm. The extracellular vesicles were negatively imprinted into the first-formed mineralized lamina. Similarly shaped and sized pits are commonly observable in organophosphatic brachiopods. They are interpreted as imprints of mucinous extracellular vesicles (Williams 2003).

\section{Ectodermal cell moulds}

The large tubercles of Mesoconularia (?) lukesi sp. nov. exhibit a distinct boundary between the "cap" and adjoining lamella (Fig. 4D). Occasional artificial breakage of a tubercle produced exfoliation of the "cap" from the adjoining lamella. The exposed external surface of the adjoining lamella shows a network of subequally sized subhexagonal polygons (Fig. 4E). The diameters of polygons are $10 \mu \mathrm{m}$ to $15 \mu \mathrm{m}$. They may be arranged fairly regularly being closely packed in a honeycomb arrangement (Fig. 4E). The

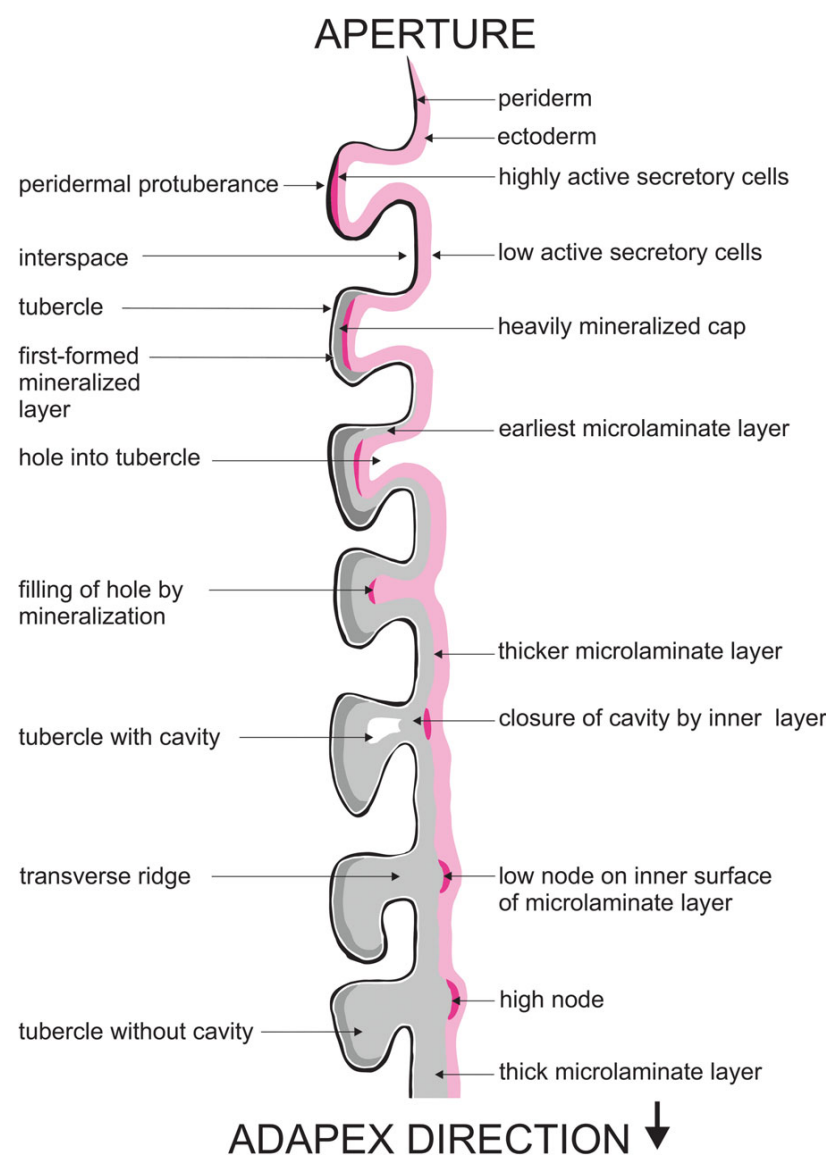

Figure 7. Mesoconularia (?) lukesi sp. nov. Diagrammantic reconstruction of a conulariid test wall in the early growth stages, and hypothetic soft tissues of a conulariid adjacent to the inner wall of the test. Initially, the organic periderm (black) was gradually strengthened by the thin first-formed lamina (white), in the adapical direction followed by a formation of the hardly mineralized "cap" of tubercle (dark grey) at a chamber of peridermal protuberance. Next centripetal mineralization (pale grey) completely filled the peridermal protuberance (= tubercle) or left the empty chamber inside the tubercle. Newly accreted laminae of multilaminate layer form the elevated node centripetally to the tubercle and reinforces the wall of the test between the tubercles. Secretory ectoderm (pale pink) with more active sectetory cell clusters (dark pink).

surface of other tubercle (Fig. 4F) exhibits a less regular polygonal network. They have subquadrate, pentagonal to polygonal and/or elongate outline. Diameter of these polygons ranges from $8 \mu \mathrm{m}$ to $15 \mu \mathrm{m}$. Surfaces of the polygons are weakly convex (= concave on surface of early accreted inner layer), with boundaries formed by a shallow groove.

The general arrangement of polygons and their sizes are similar to the epithelial cell moulds preserved on the internal surface of shells of organophosphatic brachiopods. Brachiopod epithelial cell moulds arranged in a fine hexagonal network were firstly observed in the Lower Palaeozoic obolids (Curry \& Williams 1983). Subsequently they have been ascertained in the Ordovician acrotretoids (McClean 1988, Mergl 2002, Winrow \& 


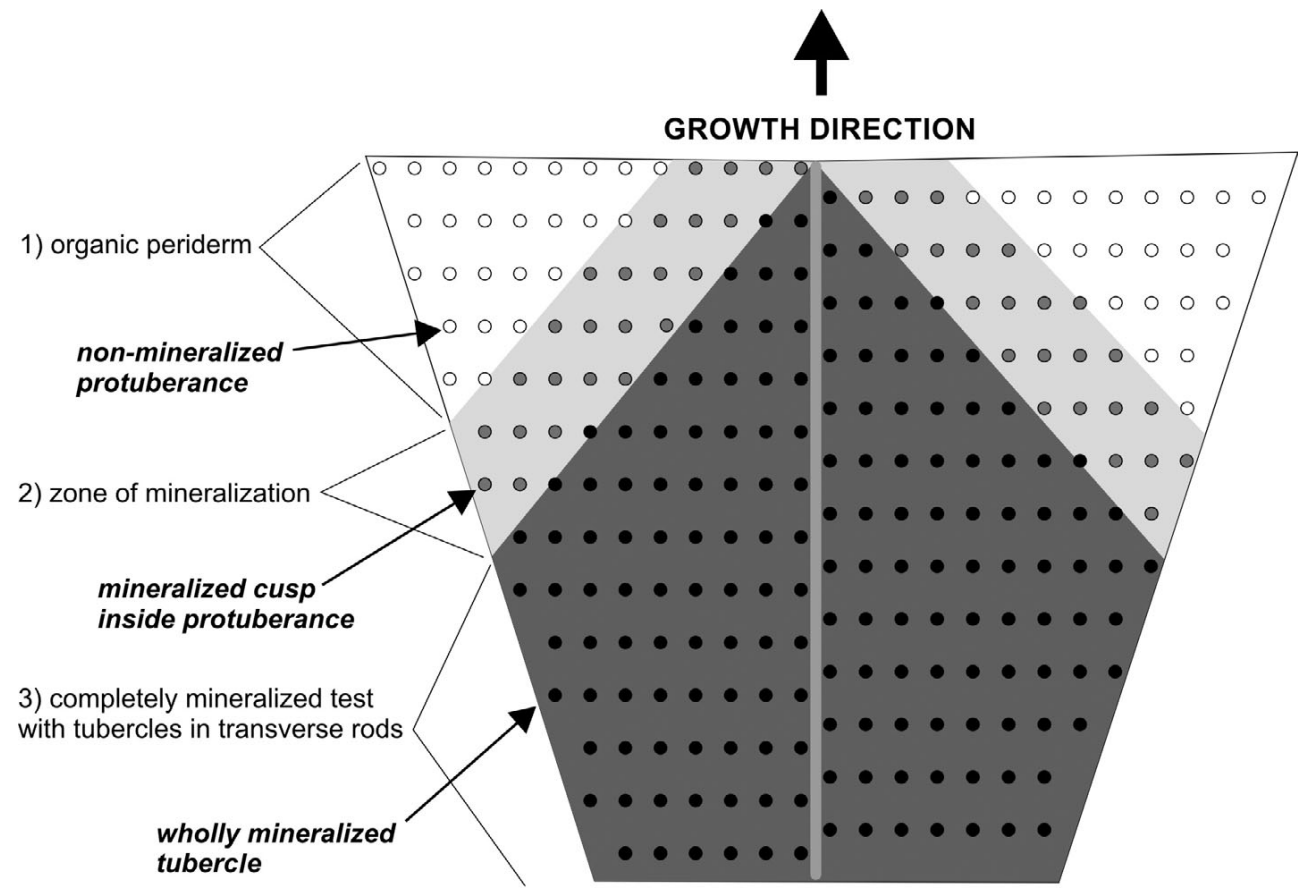

Figure 8. Diagrammatic scheme of successive stages of mineralization near the apertural end of the conulariid test.

Sutton 2012) and the Silurian and the Devonian discinoids (Mergl 2001, Mergl \& Ferrová 2009). Size of suggested conulariid ectodermal cell moulds is comparable with size of epidermal cell moulds of the brachiopod epithelium, with diameter around $10 \mu \mathrm{m}$ to $15 \mu \mathrm{m}$. However, the conulariid ectodermal cell moulds differ by less regular shape and less regular arrangement from brachiopod epithelial cell moulds. These differences are consistent with the generally accepted cnidarian affinity of the conulariids. The ectoderm of cnidarians is formed by diverse shaped cells (Ruppert et al. 2004). The largest are epitheliomuscular cells, with intercalated smaller receptor cells, interstitial cells and cnidocytes. Consequently, the ectodermal cell layer of a cnidarian has a less uniform apical surface than the epithelium of the brachiopod mantle. If the polygons are actually the imprints of ectodermal cells, then these imprints were formed by clusters cells, which produced the protuberances in the organic periderm, the mineralized test, and the internal nodes at the same place of the test.

\section{Microstructure, chemical and mineralogical composition}

The analysis should confirm differences or conformity in chemical composition of the translucent "cap" observed in Mesoconularia (?) lukesi sp. nov. The SEM study revealed that the test of Mesoconularia (?) lukesi is formed by homogeneous microstructure (Fig. 5B, E) which is porous and consists of small irregular crystals. Distinct lamination visible in thin sections (Fig. 6) as well as on freshly broken surfaces by electron microscopy (Fig. 5B, E) probably represents primary growth features. Van Iten (1992b) also found the same lamination in certain Ordovician, Devonian and Pennsylvanian conulariids and by Ford (2011) and Ford et al. (2016) in Ordovician and Mississippian conulariids.

The porous nature of the test being developed uniformly in the inner as well as outer layers makes an exact quantitative analysis of its chemical composition by electron microprobe impossible. Nevertheless, obtained data revealed that $\mathrm{O}, \mathrm{C}, \mathrm{F}, \mathrm{P}$ and $\mathrm{Ca}$ are the main elements, which form the test of Mesoconularia (?) lukesi. The same result was obtained by Ford et al. (2016) for Paraconularia missouriensis (Meek \& Worthen) from the Lower Mississippian Fort Payne Formation of Tennessee. In addition to these major elements several trace elements including $\mathrm{Mg}$, $\mathrm{Fe}$ and $\mathrm{Na}$ were detected in all analyses. The relative abundances of the major elements in all 25 analysed points, including different parts of the outer (= "cap") and inner layers are rather constant, suggesting that the two layers have identical chemical compositions. Ratio of main elements inferred from the electron microprobe analyses suggest that the test in Mesoconularia (?) lukesi was formed by carbonate-fluorapatite. The X-ray powder diffraction analysis confirmed the presence of an apatite structure (Fig. 10) with lattice parameters: $\mathrm{a}=9.351(4) \AA$ and $\mathrm{c}=6.8876(2) \AA$. Electron microprobe analyses clearly evidence for rather high C content in analysed fluorapatite. McClellan (1980) showed that the $\mathrm{CO}_{3}{ }^{2-}$ ion substitutes for $\mathrm{PO}_{4}{ }^{3-}$ and may occupy $30 \%$ of the $\mathrm{PO}_{4}{ }^{3-}$ sites in the mineral structure. The 


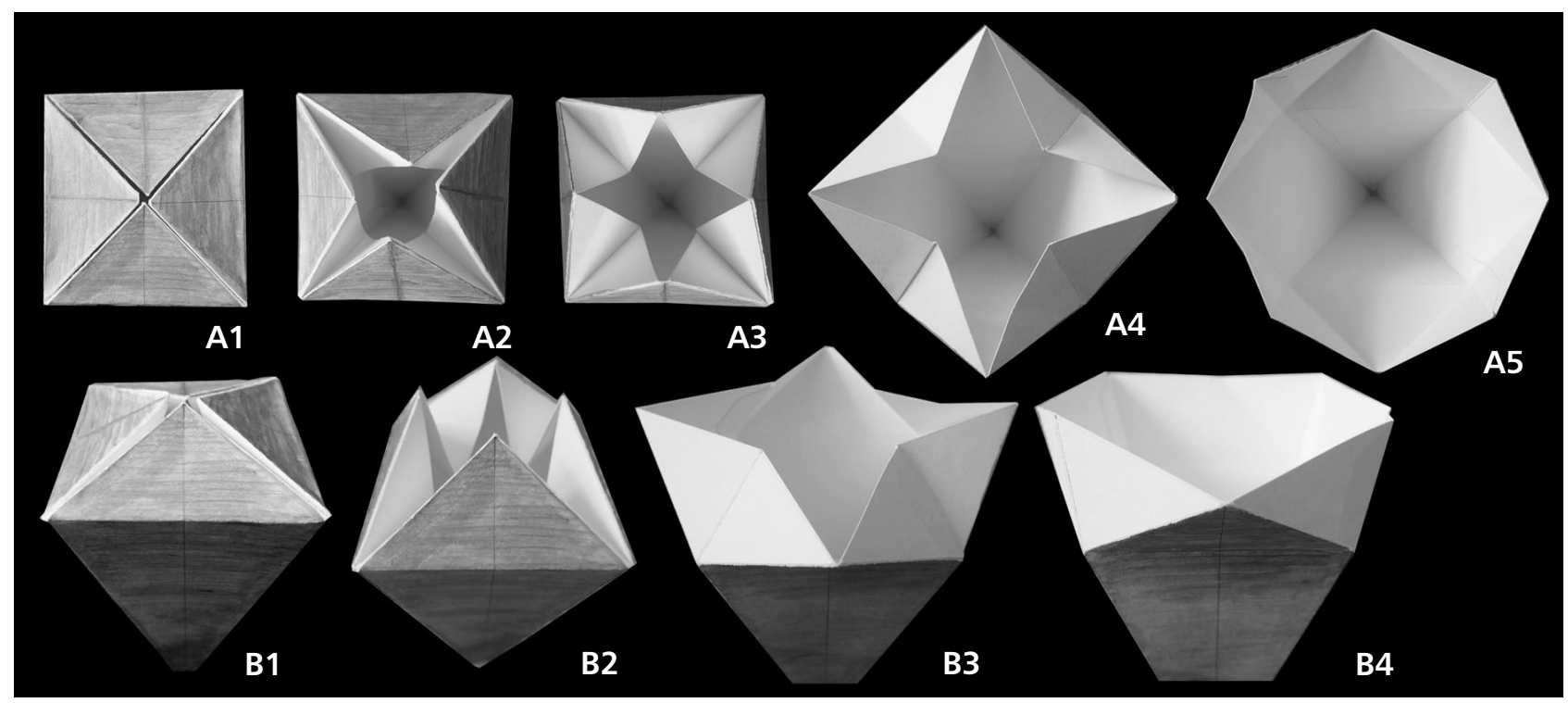

Figure 9. Aperture of generalised conulariid showing steps in closure of mineralized lappets (grey) and non- or weakly mineralized "kite-like" lappets (white); a paper model.

latter substitution considerably changing $c$ parameter of crystal lattice may be used for estimation of concentration of $\mathrm{CO}_{3}{ }^{2-}$ within apatites. Empirical equation (Schuffert et al. 1990) using differences in position of 004 and 410 reflections (Fig. 10B) suggests that carbonate ion concentration in apatite of Mesoconularia (?) lukesi about 1.5 wt.\%. This value as well as high concentration of fluorine determinates apatite of Mesoconularia (?) lukesi test as francolite what is a carbonate rich variety of carbonate-fluorapatite (McConnell 1973).

Chemical, mineralogical as well as microstructure compositions of the test of Mesoconularia (?) lukesi resemble compositions found in the Ordovician species of Conularia as well as problematic cnidarian genus Sphenothallus (Vinn \& Kirsimäe 2015) (Fig. 10A).

\section{Reconstruction of thecal growth}

There is general agreement that the conulariid theca grew at the apertural end, which was occasionally closed by triangular apertural lappets. Van Iten (1992b) proposed that conulariids possessed an external set of weakly or nonmineralized lamellae, situated adaxially to the mineralized lamellae and produced by soft epidermal tissues lining the apertural margin. We follow this suggestion. Additionally, we offer the following model of the main steps in the growth of the skeleton of Mesoconularia (?) lukesi sp. nov. (Fig. 7). Variations on this model may also apply to the growth of other conulariids, many of which differ from Mesoconularia (?) lukesi in lacking nodes or in lacking a heavily mineralized node cap.
The thickness of the faces increased by centripetal accretion (Van Iten 1992b) of laminae to previously formed organic or mineralized laminae. Based on the preservation of Mesoconularia (?) lukesi it is likely that the first mineralized lamina was very thin (Fig. 5F) and duplicated the topography of the inner surface of the periderm. Following the formation of this lamina, heavy mineralization occurred exclusively within the peridermal protuberances. The mineralized "cap" inside the peridermal protuberances was likely the first heavily mineralized part in an organic or weakly mineralized lining along the aperture. Additional mineralized laminae were accreted onto the underside of the "caps" and onto the inner side of the weakly mineralized initial lamina. This and subsequently formed laminae of the multilamellar inner layer were surely accreted by epidermal gland cells. The inner layer progressively thickened during ontogeny and added considerably to the rigidity of the theca. Thinner and flexible parts of the theca remained near the growing apertural end, where the lappets and adjacent walls of the theca could be folded.

It is likely that the clusters of cells that secreted the organic (= organic periderm) and subsequent phosphatic and organic (= layered wall) layers had a fixed location in the epidermis. Initially, the clusters of more active secretory cells formed the external protuberances in organic periderm. Subsequently, the same cell clusters produced the mineralized tubercles on the external face and the elevated nodes on the internal surface of the test. Less active secretory epithelium produced smaller amounts of a phosphatic substance, producing the thinner lamellae in the interspaces joining the base of the tubercles and ribs. It is noteworthy that the spacing of the tubercles and internal 

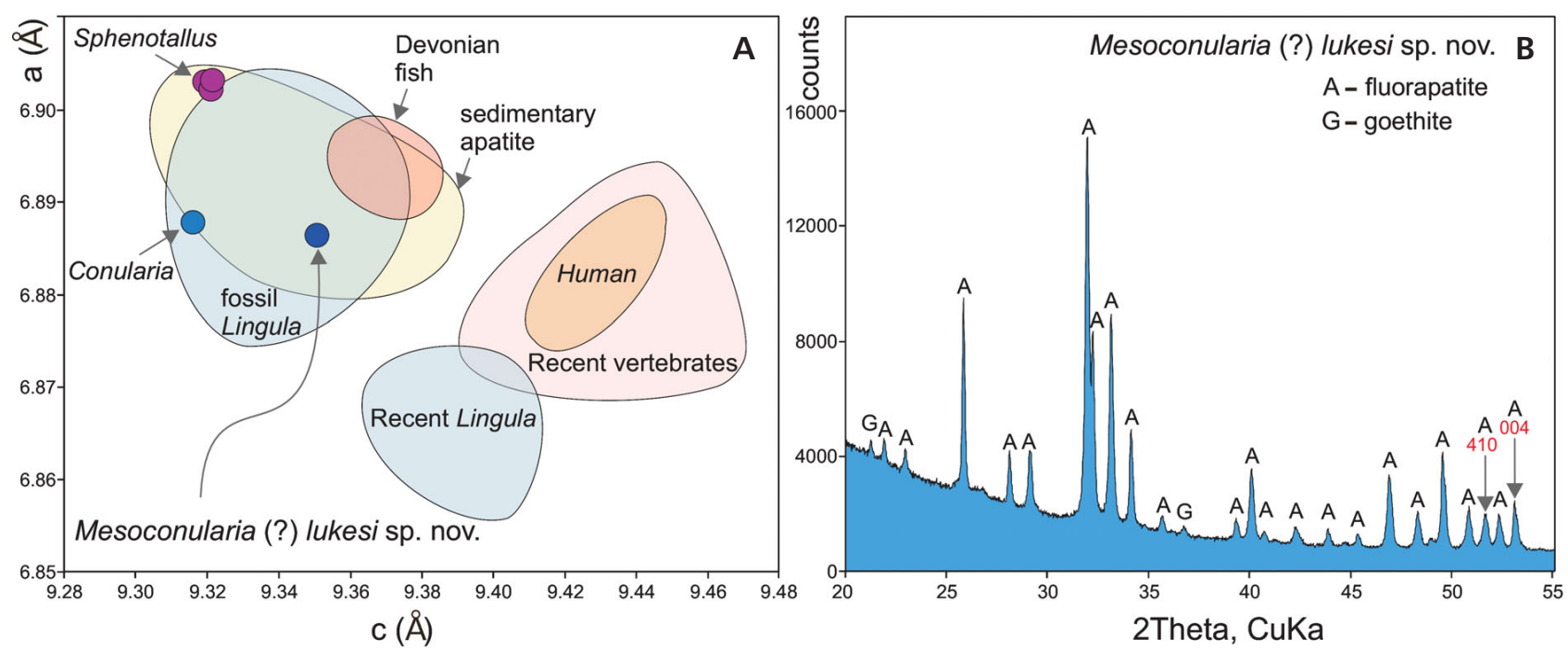

Figure 10. A - lattice parameters of Mesoconularia (?) lukesi sp. nov. francolite shown in diagramm of Vinn \& Kirsimäe (2015) compared with those of Conularia sp. and Sphenothallus and other biological and sedimentary apatites (data from Nemliher 1999). • B - X-ray powder diffraction pattern of Mesoconularia (?) lukesi francolite from the angular range of $10-55^{\circ}$, which was used for calculation of its lattice parameters after substraction goethite diffractions (contaminat ion of conulariid test surface). Francolite diffractions 410 and 004 which were used to estimate its carbonate ion content are marked in red colour.

nodes is regular. This pattern indicates a regular and fixed location of secretory cell clusters that produced the protuberances, tubercles, and nodes. Thus the ectoderm of the sides of the polyp was likely in a permanent and changeless contact with inner surface of the test wall throughout the life of the animal. Therefore, the animal could not detach the soft body from the inner surface of the theca. The periderm of recent colonial hydrozoans is secreted only along the apertural margin and the polyp can move inside the periderm (Kossevitch et al. 2001). This was impossible in $M$. (?) lukesi because in such a case the secretory cells clusters occasionally altered their locations inside the theca and the discrete nodes on the internal face of the test could hardly originate. It is likely that the type of secreted material changed during ontogeny. The early formed secretory cells produced the exclusively organic substance of the periderm. Subsequently the same cell clusters alternately accreted the organic and the inorganic substances of the early formed lamellae of the shell (Ford et al. 2016). In Mesoconularia (?) lukesi, the secretory cell clusters initially produced the organic periderm, as in other conulariids, but then large amounts of phosphatic material to form the massive cap of the tubercles, and finally continued by alternation of organic and phosphatic laminae accretion.

\section{Discussion}

Protective exterior structures evolved in many organisms over millions of years. One of their functions is mechanical protection from predators. Predators use various techniques including penetration, drilling, fatigue, peeling, chipping, crushing, and kinetic attacks (Lowenstam \& Weiner 1989). The prey may carry armour or offensive weapons to avoid predation. Armour is typically exemplified by spines or simple strengthening of the outer shells layers, but even more elaborate structures exist (Yao et al. 2010). Indeed, the multilayered, bicomposite design of the conulariid test was effectively hard owing to the presence of the calcium phosphate. The test was also flexible, withstanding some mechanical deformation (Ford et al. 2016).

A similar composite shell structure is known in organophosphatic brachiopods (Williams \& Holmer 1992, Williams 1997). As indicated in fossils records, the brachiopod shells were slightly flexible but also effectively hard. Shell taphonomy indicates that their brittleness increased with thickness and lower content of organic matter. The folding of the apertural lappets indicates some flexibility of the conulariid faces (Van Iten et al. 2008, Ford et al. 2016), although the test retained the hardness of the calcium phosphate and its wall was steadily strengthened by centripetal mineralization.

The advantage of the greater hardness of the calcium phosphate shell compared with the calcium carbonate shell has been demonstrated experimentally the extant, fixo-sessile discinid brachiopod, Discinisca. This animal is able to scratch calcium carbonate shelled competitors by rapid motions of its shell (LaBerbera 1985). Unlike molluscan calcium carbonate shells and calcitic brachiopod shells (Leighton 2001, 2003; Hoffmeister et al. 2003; Kelley \& Hansen 2003), there are very few recorded cases of predatory borings or piercing on organophosphatic fossil 
brachiopod shells (Conway Morris \& Bengtson 1994) or conulariids (Bischoff 1973, Mapes et al. 1989). Hardness itself may provide enough protection against drilling or peeling by smaller predators, for example gastropods or small cephalopods, although the hardness of radular teeth is comparable to that of calcium phosphate shells (Lowenstam 1962).

Increased selection pressure from durophagous predators as well as distinct changes in the Devonian benthic communities was first described by Signor \& Brett (1984) as "Middle Palaeozoic Marine Revolution". The increasing importance of jawed nektonic or nekto-benthonic vertebrates equipped with calcium-phosphate teeth represented a new and serious danger for many invertebrates during the early Devonian. During last two decades there has been a growing body of evidence that the Devonian was a time of reconstruction of benthic as well as planktonic communities (Klug et al. 2010). Nützel \& Frýda (2003) noted a distinct macroevolutionary trend in the morphology of gastropod larvae, which trend has also been interpreted as a reaction to increasing predation pressure. Later, Seuss et al. (2012) showed that some mid-Palaeozoic gastropod groups gradually evolved larval armour and tight coiling. Berkyová et al. (2007) were the first investigators to document unsuccessful predation on mid-Palaeozoic plankton. Lucas (2012) suggested that the smaller size and thicker test of post-Devonian conulariids evolved as a reaction to increasing durivorous predation in marine ecosystems.

The shell of Mesoconularia (?) lukesi sp. nov. has an unusual surface among conulariids. Most conulariids have tubercles or nodes that are slightly elevated above the surface of the interspaces, some rather high (Percival 2009), but not extending much outside the transverse ribs. The interspaces have a continuous but thinner organophosphatic wall of the test. The interspaces were more flexible but likely more prone to breakage by predators than the transverse ridges. There are various types of breakages observed in conulariids (Babcock et al. 1987, Mapes et al. 1989, Brabcová 2002), and some of them may have been caused by jawed predators (cephalopods and vertebrates). The evolutionary response of conulariids to increased durophagy could not have been general reinforcement of the entire shell wall, as this would have resulted in reduced flexibility of the shell and thus loss of the ability to close the aperture by means of lappets. Furthermore, from the standpoint of metabolism, there could have been a problem producing enough calcium phosphate to strengthen the test.

In Mesoconularia (?) lukesi, this defensive requirement was solved by reinforcement of the tops of the tubercles (= caps) and by their extension over the gaps and interspaces between the transverse ribs. This "superstructure" is built of heavily mineralized "caps" and formed a hard, robust protective layer above a comparatively thinner and therefore less protective subjacent wall of the test.
It is a kind of "chain armour". This design retained the advantage of flexibility of the test necessary for moderate elastic deformation and movement of apertural lappets but offered the efficiently defensive outside surface. The hardness of the phosphatic tubercles and smooth surface were sufficiently protective against the comparably hard tooth enamel of smaller jawed vertebrates, in the early Devonian represented primarily by acanthodians. It is likely that the ascendancy of calcium phosphate over the organic substance concentrated in the tubercle cap is a reaction to the demand of higher resistance and protective function of the external surface of the test. By analogy, the similar protective function has ganoine, a glassy multilayered cover of rod-like apatite crystallites in the ganoid scales of ray-finned fished.

The surface with rows of thorny tubercles of Conularia sp. likely represents another protective structure. The presence of spines on the exterior surface of shells is generally accepted as a defensive device (Seilacher 1991, Kohn 1999). It is unlikely that spinose tubercles preserved on the surface of Conularia sp. were some sort of a balance organ, a comb-like feeding organ, or an organ supporting the stability of the animal on the sea floor, although some conulariids were semi-infaunal (Van Iten et al. 2012). Rows of small pointed thorns on the surface of Conularia sp. formed a protective structure, which was able sufficiently to deter some small predators. It has been shown, for example, that small predators such as carnivorous gastropods cannot manoeuvre on a thorny surface as easily as on a smooth surface (Willman 2007). In a similar way, the spines on bryozoans provide an effective defence against nudibranchs (Yoshioka 1982). However, the small size of the spines on Conularia sp. was probably not enough effective equipment against the larger gnathostomes.

In summary, we suggest that the heavily mineralized and extended tubercles and spines of Mesoconularia (?) lukesi represent substantially better protective structures than the smooth ribs, simple elevated nodes, or simple tubercles of other conulariids.

\section{Acknowledgements}

The authors are greatly indebted to J. Nebesářová, J. Vaněček, and T. Bílý (Academy of Science of the Czech Republic, České Budejovice) for help with the SEM study of the material. This study was supported by grants of the Grant Agency of the Czech Republic GAČR (GA15-13310S (for M.M. and J.F.) and P210-12-2018 (for L.F). We thank F. Laufek and O. Pour (both from the Czech Geological Survey, Prague) for their help with electron microprobe and X-ray powder diffraction analyses. Review comments by H. Van Iten, N.C. Hughes and one anonymous reader improved the original manuscript substantially. This is a contribution to IGCP Project 591: The Early to Middle Palaeozoic Revolution. 


\section{References}

Archiac, E.J.A. D' \& Verneuil, E.P. DE 1842. On the fossil of the older deposits in the Rhenish provinces, preceded by a general survey of the fauna of the Palaeozoic rocks, and followed by a tabular list of the organic remains of the Devonian System in Europe. Transactions of the Geological Society of London 2, 6(2), 303-410.

BАВСОСK, L.E. 1991. The enigma of conulariid affinities, 133-143. In Simonetta, A.M. \& Conway-Morris, S. (eds) The Early Evolution of Metazoa and the Significance of Problematic Taxa. Cambridge University Press, Cambridge.

BABCOCK, L.E. \& Feldmann, R.M. 1986a. The phylum Conulariida, 135-147. In Hoffmann, A. \& Nitecki, M.H. (eds) Problematic fossil taxa. Oxford University Press, Oxford.

Babcock, L.E. \& Feldmann, R.M. 1986b. Devonian and Mississippian Conulariids of North America. Annals of Carnegie Museum 55, 349-479.

BabCock, L.E., Feldmann, R.M. \& Wilson, M.T. 1987. Teratology and pathology on some Paleozoic conulariids. Lethaia 20(2), 93-105. DOI 10.1111/j.1502-3931.1987.tb00765.x

BARRANDE, J. 1867. Systême silurien du centre de la Bohême. Ière Partie. Tome 3. Classe des Mollusques, Ordre des Ptéropodes. 179 pp. Prague \& Paris.

Berkyová, S. 2004. Middle Devonian Tentaculitoidea from the late generation of fillings of the neptunian dyke in the Koněprusy area (Prague Basin, Czech Republic). Journal of the Czech Geological Society 49(3-4), 147-155.

Berkyová, S. 2009. Lower-Middle Devonian (upper EmsianEifelian, serotinus-kockelianus zones) conodont faunas from the Prague Basin, the Czech Republic. Bulletin of Geosciences 84(4), 667-686. DOI 10.3140/bull.geosci.1153

BERKYOVÁ, S., FRÝDA, J. \& LUKEŠ, P. 2007. The first documentation of unsuccessful predation on the Middle Palaeozoic plankton. Acta Palaeontologica Polonica 52(2), 407-412.

BISCHOFF, G.C.O. 1973. On the nature of the conodont animal. Geologica et Palaeontologica 7, 147-174.

BisCHOFF, G.C.O. 1978. Internal structures of conulariid tests and their functional significance, with special reference to the Circoconulariina n. suborder (Cnidaria, Scyphozoa). Senckenbergiana lethaea 59(4/6), 275-327.

BouČEK, B. 1928. Revise českých paleozoických konulárií. Palaeontographica Bohemiae 11, 1-108.

BouČEK, B. 1939. Conulariida, 111-131. In SCHINDEwolf, O.H. (ed.) Handbuch der Paläozoologie 2A. Gebrüder Borntraeger, Berlin.

BouČEK, B. \& UlRich, F. 1929. O skořápce rodu Conularia Miller. Věstník Státního geologického ústavu Československé republiky 5, 1-25.

BrabcovÁ, Z. 2002. Patologické znaky na exoskeletonech konularií (spodní paleozoikum, pražská pánev). Zprávy o geologických výzkumech v roce 2001, 86-87.

BRoOD, K. 1995. Morphology, structure, and systematic of the conulariids. Geologiska Föreningen i Förhandlingar 117, 121-137. DOI 10.1080/11035899509546208

Chlupáč, I. 1955. Stratigraphical study of the oldest Devonian beds of the Barrandian. Sborník Ústředního ústavu geologického, Oddíl geologický 21(2), 91-224.

CHLUPÁČ, I. 1957. Facial development and biostratigraphy of the Lower Devonian of Central Bohemia. Sborník Ústředního ústavu geologického, Oddíl geologický 23, 369-485.

CHLuPÁČ, I. 1981. Stratigraphic terminology of the Devonian in Central Bohemia (Barrandian area, Czechoslovakia). Věstník Českého geologického ústavu 56(5), 263-270.

CHLuPÁČ, I. 1996. Neptunian dykes in the Koněprusy Devonian: Geological and palaeontological observations. Věstník Českého geologického ústavu 71(3), 193-208.

Chlupáč, I. 1998. K faciím a stratigrafii spodnodevonského útesového komplexu u Koněprus. Věstník Českého geologického ústavu 73(1), 1-13.

Chlupáč, I. 1998. Devonian, 101-133. In Chlupáč, I. et al. Palaeozoic of the Barrandian (Cambrian to Devonian). Czech Geological Survey, Prague.

Chlupáč́, I., HavlíčeK, V., KŘíž, J., Kukal, Z. \& ŠTorch, P. 1998. Palaeozoic of the Barrandian (Cambrian to Devonian). 183 pp. Czech Geological Survey, Prague.

Chlupáč, I., Hladil, J. \& Lukeš, P. 1986. Barrandian Moravian Karst 1986. Excursion - Guidebook. Subcomission on Devonian Stratigraphy of the International Commission on Stratigraphy. 62 pp. Ústřední ústav geologický, Praha.

Chlupáč, I. \& Kukal, Z. 1988. Possible global events and the stratigraphy of the Barrandian Paleozoic (Cambrian-Devonian, Czechoslovakia). Sborník geologických věd, Geologie 43, 83-146.

Chlupáč, I., Lukeš, P. \& Zikmundová, J. 1979. The Lower/Middle Devonian boundary beds in the Barrandian area. Geologica et Palaentologica 13, 125-156.

Conway Morris, S. \& Bengtson, S. 1994. Cambrian predators: possible evidence from boreholes. Journal of Paleontology 68, 1-23. DOI 10.1017/S0022336000025567

CurRy, G.B. \& Williams, A. 1983. Epithelian moulds on the shells of the early Palaeozoic brachiopod Lingulella. Lethaia 16(2), 111-118. DOI 10.1111/j.1502-3931.1983.tb01706.x

Cusack, M., Williams, A. \& Buckmann, J.O. 1999. Chemicostructural evolution of linguloid brachiopod shells. Palaeontology 42(5), 799-840. DOI 10.1111/1475-4983.00098

FELDMANN, R.M. \& BABCOCK, L.E. 1986. Exceptionally preserved conulariids from Ohio - reinterpretation of their anatomy. $\mathrm{Na}$ tional Geographic Research 2, 464-472.

Ferrová, L. 2010. Biostratigraphy, sedimentology, and paleoecology of the Chýnice Limestone at Čr řinka locality near Bubovice. 96 pp. Master's thesis, Charles University, Prague, Czech Republic.

Ferrová, L., FrÝdA, J. \& LuKeš, P. 2012. High-resolution tentaculite biostratigraphy and facies development across the Early Devonian Daleje Event in the Barrandian (Bohemia): implication for global Emsian stratigraphy. Bulletin of Geosciences 87(3), 587-624. DOI 10.3140/bull.geosci.1336

FORD, R.C. 2011. Conulariid test microstructure and mineralogy. 43 pp. Master's thesis, Kansas State University, Manhattan, Kansas, USA.

Ford, R.C., VAn Iten, H. \& Clark, G.R. 2016. Microstructure and composition of the periderm of conulariids. Journal of $\mathrm{Pa}$ leontology 90(3), 389-399. DOI 10.1017/jpa.2016.63

FRÝDA, J. 1992. Mode of life of a new onychochilid mollusc from 
the Lower Devonian of Bohemia. Journal of Paleontology 66, 200-205. DOI 10.1017/S0022336000033710

FRÝDA, J. 2001. Discovery of a larval shell in Middle Palaeozoic subulitoidean gastropods with description of two new species from the Early Devonian of Bohemia. Bulletin of the Czech Geological Survey 76, 29-37.

Frýda, J., Ferrová, L., Berkyová, S. \& Frýdová, B. 2008. A new Early Devonian palaeozygopleurid gastropod from the Barrandian (Bohemia) with notes on the phylogeny of the Loxonematoidea. Bulletin of Geosciences 83(1), 93-100. DOI 10.3140/bull.geosci.2008.01.093

Frýda, J., Racheboeuf, P.R., FrÝdová, B., Ferrová, L., Mergl, M. \& Berkyová, S. 2009. Platyceratid gastropods - stem group of patellogastropods, neritimorphs or something else? Bulletin of Geosciences 84(1), 107-120.

DOI 10.3140/bull.geosci.1125

HaVlíčEK, V. \& KuKal, Z. 1990. Sedimentology, benthic communities, and brachiopods in the Suchomasty (Dalejan) and Acanthopyge (Eifelian) Limestones of the Koněprusy area (Czechoslovakia). Sborník geologických věd, Paleontologie 31, 105-205.

HAVLÍČEK, V. \& VANĚK, J. 1996. Brachiopods and trilobites in the Chýnice Limestone (Emsian) at Bubovice (Čeřinka hillside; Prague Basin). Palaeontologica Bohemiae 2, 1-16.

Hoffmeister, A.P., Kowalewski, M., Bambach, R.K. \& BAumiller, T.K. 2003. Intense drilling in the Carboniferous brachiopod Cardiarina cordata Cooper, 1956. Lethaia 36, 107-118. DOI 10.1080/00241160310000408

House, M.R. 1985. Correlation of mid-Palaeozoic ammonoid evolutionary events with global sedimentary perturbations. Nature 313, 17-22. DOI 10.1038/313017a0

Hughes, N.C., Gunderson, G.O. \& Weeden, M.J. 2000. Late Cambrian conulariids from Wisconsin and Minnesota. Journal of Paleontology 74(5), 828-838. DOI $10.1017 / \mathrm{S} 0022336000033035$

HuGHES, R.G. 1992. Morphological adaptations of the perisarc of the intertidal hydroid Dynamena pumila to reduce damage and enhance feeding efficiency. Scientia Marina 56(2-3), 269-277.

JERRE, F. 1988. Silurian conulariids from the Lower Visby Beds on Gotland. Examensarbete i Geologi vid Lunds universitet. Historisk geologi och paleontologi 25, 1-17.

JERRE, F. 1994. Anatomy and phylogenetic significance of Eoconularia loculata, a conulariid from the Silurian of Gotland. Lethaia 27, 97-109. DOI 10.1111/j.1502-3931.1994.tb01562.x

John, D.L., Hughes, N.G., Galaviz, M.I., Gunderson, G.O. \& MEYER, R. 2010. Unusually preserved Metaconularia manni (Roy, 1935) from the Silurian of Iowa, and the systematics of the genus. Journal of Paleontology 84(1), 1-31. DOI 10.1666/09-025.1

Kelley, P.H. \& HANSEN, T.A. 2003. The fossil record of drilling predation on bivalves and gastropods, 113-133. In KELLEY, P.H., Kowalewski, M. \& Hansen, T.A. (eds) Predator-prey interactions in the Fossil Record: Topics in Geobiology Series 20. Plenum Press/Kluwer, New York.

Kiderlen, H. 1937. Die Conularien. Über Bau and Leben der ersten Scyphozoa. Neues Jahrbuch für Mineralogie, Beilage-Band 77, 113-169.
KLAPPER, G. 1977. Lower-Middle Devonian boundary conodont sequence in the Barrandian area of Czechoslovakia. $\breve{C}$ asopis pro mineralogii a geologii 22(4), 401-410.

Klapper, G., Ziegler, W. \& Mashkova, T. 1978. Conodonts and correlation of Lower-Middle Devonian boundary beds in the Barrandian area of Czechoslovakia. Geologica et Paleontologica 12, 103-116.

Klug, C., Kröger, B., Kiessling, W., Mullins, G.L., Servais, T., FrÝdA, J., Korn, D. \& Turner, S. 2010. The Devonian Nekton Revolution. Lethaia 43, 465-477. DOI 10.1111/j.1502-3931.2009.00206.x

КонN, A.J.E. 1999. Anti-predator defenses of shelled gastropods, 169-181. In SAvazzi, E. (ed.) Functional morphology of the invertebrate skeleton. John Willey and Sons, Chichester.

Kossevitch, I.A., Hermann, K. \& Berking, S. 2001. Shaping of colony elements in Laomedea flexuosa Hinks (Hydrozoa, Thecaphora) inludes a temporal and spatial control of skeleton hardening. The Biological Bulletin 201, 417-423. DOI 10.2307/1543619

KovANDA, J. et al. 1984. Vysvětlivky k základní geologické mapě ČSSR 1 : 25000 12-412 Rudná. 112 pp. Ústřední ústav geologický, Praha.

KozŁowsKi, R. 1968. Nouvelles observations sur les Conulaires. Acta Palaeontologica Polonica 13(4), 497-531.

KuKLA, J. 1952. Zpráva o výsledcích výzkumů jeskyní na Zlatém koni u Koněprus v roce 1951, prováděných Krasovou sekcí Př́rodovědeckého klubu v Praze. Český kras 5.

LABARbera, M. 1985. Mechanism of spatial competition of Discinisca strigata (Inarticulata, Brachiopoda) in the intertidal of Panama. Biology Bulletin 168, 101-105. DOI $10.2307 / 1541176$

Leighton, L.R. 2001. New example of Devonian predatory boreholes and the influence of brachiopod spines on predator success. Palaeogeography, Palaeoclimatology, Palaeoecology 165, 53-69. DOI 10.1016/S0031-0182(00)00153-X

LEIGHTON, L.R. 2003. Morphological response of prey to drilling predation in the Middle Devonian. Palaeogeography, Palaeoclimatology, Palaeoecology 201, 221-234. DOI 10.1016/S0031-0182(03)00627-8

Leme, J.M., Simões, M.G., Marques, A.M. \& Van Iten, H. 2008. Cladistic analysis of the Suborder Conulariina Miller and Gurley, 1896 (Cnidaria, Scyphozoa; Vendian-Triassic). Palaeontology 51(3), 649-662. DOI 10.1111/j.1475-4983.2008.00775.x

LowENSTAM, H.A. 1962. Goethite in radular teeth of recent marine gastropods. Science 137, 279-280.

DOI 10.1126/science.137.3526.279

Lowenstam, H.A. \& Weiner, S. 1989. On biomineralization. 324 pp. Oxford University Press, New York.

LuCAs, S.G. 2012. The extinction of the Conulariids. Geosciences 2012(2), 1-10. DOI 10.3390/geosciences2010001

MAPES, R.H., FARHER, T.R. \& BABCOCK, L.E. 1989. Sublethal and lethal injuries of Pennsylvanian conulariids from Oklahoma. Journal of Paleontology 63, 34-37.

DOI 10.1017/S0022336000040920

Mergl, M. 2001. Lingulate brachiopods of the Silurian and Devonian of the Barrandian. Acta Musei nationalis Pragae, Series $B$ - historia naturalis $57,1-49$.

Mergl, M. 2002. Linguliformean and craniiformean brachiopods 
of the Ordovician (Třenice to Dobrotivá Formations) of the Barrandian, Bohemia. Acta Musei nationalis Pragae, series $B$ - historia naturalis 58, 1-82.

Mergl, M. \& Ferrová, L. 2009. Lingulate brachiopods from the Chýnice Limestone (upper Emsian, Barrandian; Czech Republic). Bulletin of Geoscinces 84(3), 525-546.

DOI 10.3140/bull.geosci.1245

Mergl, M. \& JiMÉNEZ-SÁNCHEZ, A. 2015. Lingulate brachiopods from the Suchomasty Limestone (upper Emsian) of the Barrandian, Czech Republic. Bulletin of Geosciences 90(1), 173-193. DOI 10.3140/bull.geosci.1533

MCClEAN, A.E. 1988. Epithelian moulds from some Upper Ordovician acrotretide brachiopods of Ireland. Lethaia 21, 43-50. DOI 10.1111/j.1502-3931.1988.tb01752.x

McClellan, G.H. 1980. Mineralogy of carbonate-fluorapatite. Journal of the Geological Society London 137, 675-681. DOI 10.1144/gsigs.137.6.0675

McConnell, D. 1973. Apatite: Its Crystal Chemistry, Mineralogy, Utilization, and Geologic and Biologic Occurrences. 86 pp. Springer, Vienna. DOI 10.1007/978-3-7091-8314-4

Moore, R.C. \& Harrington, H.J. 1956. Conulata, F27-F38. In Moore, R.C. (ed.) Treatise on invertebrate paleontology, Part $F$, Coelenterata. Geological Society of America \& University of Kansas, New York \& Lawrence.

NemLiner, J. 1999. Mineralogy of Phanerozoic Skeletal and Sedimentary Apatites: an XRD Study. 134 pp. Tartu University, Tartu.

NÜTZEL, A. \& FRÝdA, J. 2003. Paleozoic plankton revolution: evidence from early gastropod ontogeny. Geology 31, 829-831. DOI 10.1130/G19616.1

Percival, I.G. 2009. Rare fossils (Conulata; Rostroconchia; Nautiloidea) from the Late Ordovician of Central New Wales. Proceedings of the Linnean Society of New South Wales 130, 179-191.

Robson, S.P. \& Young, G.A. 2013. Late Ordovician conulariids from Manitoba, Canada. Journal of Paleontology 87(5), 775-785. DOI 10.1666/12-0370

Ruppert, E.E., Fox, R.S. \& BARnes, R.D. 2004. Invertebrate Zoology: A functional Evolutionary Approach. Seventh Edition. i-xvii, 1-963, I1-I26. Brooks/Cole, Cengage Learning.

Schuffert, J.D., Kastner, M., Emanuele, G. \& JahnKe, R.A. 1990. Carbonate-ion substitution in francolite - a new equation. Geochimica et Cosmochimica Acta 54(8), 2323-2328. DOI 10.1016/0016-7037(90)90058-S

SeILACher, A. 1991. Self-organizing mechanism in morphogenesis and evolution, 251-271. In SCHMidt-KitTler, N. \& Vogel, K. (eds) Constructional morphology and evolution. Springer-Verlag, Heidelberg.

Sendino, C., ZÁgorŠEK, K. \& Vyhlasová, Z. 2011. The aperture and its closure in an Ordovician conulariid. Acta Palaeotologica Polonica 56(3), 659-663.

DOI 10.4202/app.2010.0028

Seuss, B., Nützel, A., Scholz, H. \& FrÝda, J. 2012. The Paleozoic evolution of the gastropod larval shell: larval armor and tight coiling as a result of predation-driven heterochronic character displacement. Evolution \& Development 14, 212-228. DOI 10.1111/j.1525-142X.2012.00536.X

SignoR, P.W. \& BRETT, C.E. 1984. The mid-Paleozoic precursor to the Mesozoic marine revolution. Paleobiology 10, 229-245. DOI 10.1017/S0094837300008174

Simões, M.G., Rodrigues, S.C., Leme, J.M. \& Van Iten, H. 2003. Some Middle Paleozoic Conulariids (Cnidaria) as possible examples of taphonomic artifacts. Journal of Taphonomy 1(3), 165-189.

SOWERBy, J. 1821. The mineral conchology of Great Britain; or coloured figures and description of those remains of testaceous animals or shells, which have been preserved at various times, and depths in the Earth. Part 3, 115-160. W. Arding Company, London.

Svoboda, J. \& Prantl, F. 1948. The stratigraphy and tectonics of the Early Palaeozoic strata in the vicinity of Chýnice (English summary). Sborník Státního geologického ústavu Československé republiky 15, 1-39.

Termier, H. \& Termier, G. 1953. Les Conulariides, 1006-1013. In Pivetau, J. (ed.) Traité de paléontologie. Tome 3. Onychophores, arthropodes, echinodermes, stomocordes. Masson et Cie, Paris.

VAN ITEN, H. 1991. Evolutionary affinities of conulariids, 145-154. In SimonetTA, A.M. \& Morris, S.C. (eds) The early evolution of Metazoa and the significance of problematic fossil taxa. Cambridge University Press, Cambridge.

VAN Iten, H. 1992a. Anatomy and phylogenetic significance of the corners and midlines of the conulariid test. Palaeontology 35, 335-358.

VAN ITEN, H. 1992b. Microstructure and growth of the conulariid test: implications for conulariid affinities. Palaeontology 35, 359-372.

Van Iten, H., Burkey, M.H., Leme, J.M. \& Marques, A.C. 2014a. Cladistics and mass extinctions: the example of conulariids (Scyphozoa, Cnidaria) and the End Ordovician Extinction Event. Geologiska Föreningen i Förhandlingar 136, 275-280. DOI 10.1080/11035897.2014.880506

Van Iten, H., Leme, J.M., Rodrigues, S.C. \& Simões, M.G. 2005. Reinterpretation of a conulariid-like fossil from the Vendian of Russia. Palaeontology 48(3), 619-622. DOI 10.1111/j.1475-4983.2005.00471.x

Van Iten, H., Leme, J.M., Rodrigues, S.C. \& Simões, M.G. 2006a. New data on the anatomy of Conularia milwaukeensis Cleland, 1911 (Middle Devonian, Iowa and Wisconsin). Journal of Paleontology 80, 393-395.

DOI 10.1666/0022-3360(2006)080[0392:NDOTAO]2.0.CO;2

VAn Iten, H., Leme, J.M. \& SimõEs, M.G. 2006b. Additonal observations on the gross morphology and microstructure of Baccaconularia Hughes, Gunderson et Weedon, 2000, a Cambrian (Furongian) conulariid from the north-central USA. Palaeoworld 15, 294-306.

DOI 10.1016/j.palwor.2006.10.006

Van Iten, H., Leme, J.M., Simões, M.G., Marques, A.C. \& ColLINS, A.G. 2006c. Reassessment of the phylogenetic position of conulariids in the subphyllum Medusozoa (phylum Cnidaria). Journal of Systematical Palaeontology 4(2), 109-118. DOI 10.1017/S1477201905001793

Van Iten, H., Marques, A.C., Leme, J.M., Pacheco, M.L.A.F. \& SimÕES, M.G. 2014b. Origin and early diversification of the phylum Cnidaria Verrill: major developments in the analysis of the taxon's Proterozoic-Cambrian history. Palaeontology 57(4), 677-690. DOI 10.1111/pala.12116 
Van Iten, H., Moussa, K. \& Yahaya, M. 2008. Conulariids of the upper Talak Formation (Mississippian, Visean) of northern Niger (West Africa). Journal of Paleontology 82, 192-196. DOI 10.1666/06-083.1

VAN ITEN, H. \& \& SÜDKAMP, W. 2010. Exceptionally preserved conulariids and an edriosterois from the Hunsrück Slate (Lower Devonian, SW Germany). Palaeontology 53, 403-414. DOI 10.1111/j.1475-4983.2010.00942.x

Van Iten, H., Vyhlasová, Z., Mao-Yan, Z. \& Qian, Y. 2005. Widespread occurrence of microscopic pores in conulariids. Journal of Paleontology 79, 400-407.

DOI 10.1666/0022-3360(2005)079<0400:WOOMPI >2.0.CO;2

Vinn, O. \& KirsimäE, K. 2015. Alleged cnidarian Sphenothallus in the Late Ordovician of Baltica, its mineral composition and microstructure. Acta Palaeontologica Polonica 60(4), 1001-1008.

Werner, B. 1966a. Stephanoscyphus (Scyphozoa, Coronata) und seine direkte Abstammung von den fossilien Conulata. Helgoländer Wissenschaftliche Meeresuntersuchungen 13, 317-347. DOI 10.1007/BF01611953

Werner, B. 1966b. Morphologie, Systematik und Lebensgeschichte von Stephanoscyphus (Scyphozoa, Coronatae) sowie seine Bedeutung für die Evolution der Scyphozoa. Verhandlungen der Deutschen Zoologischen Gesellschaft in Göttingen, Zoologischer Anzeiger, Supplement 30, 397-319.

Werner, B. 1967. Stephanoscyphus Allman (Scyphozoa, Coronatae), ein rezenter Vertreter der Conulata? Paläontologische Zeitschrift 41, 137-153. DOI 10.1007/BF02988117

Werner, B. 1970. Contribution to the evolution in the genus Stephanoscyphus (Scyphozoa Coronatae) and ecology and regeneration qualities of Stephanoscyphus racemosus Komai. Publication Seto Marine Biological Laboratory 18(1), 1-20.

Williams, A. 2003. Microscopic imprints of the juvenile shells of Palaeozoic linguliform brachiopods. Palaeontology 46, 67-92. DOI 10.1111/1475-4983.00288
Williams, A. \& Cusack, M. 1999. Evolution of a rhytmic lamination in the organophosphatic shells of brachiopods. Journal of Structural Biology 126, 227-240.

DOI 10.1006/jsbi.1999.4117

Williams, A., Cusack, M. \& Buckman, J.O. 1998. Chemicostructural phylogeny of the discinoid brachiopod shell. Philosophical Transactions of the Royal Society of London B 353, 2005-2038. DOI 10.1098/rstb.1998.0350

Williams, A. \& Holmer, L.E. 1992. Ornamentation and shell structure of acrotretoid brachiopods. Palaeontology 35, 657-692.

Williams, A., James, M.A., Emig, C.C., Mackay, S., Rhodes, M.C., Cohen, B.L., Gawthrop, A.B., Peck, L.S., Curry, G.B., Ansell, A.D., Cusack, M., Walton, D., Brunton, C.H.C., MacKinnon, D.I. \& Richartdson, J.R. 1997. Introduction, i-xx, 1-539. In KAESLER, E. (ed.) Treatise on invertebrate paleontology. Part H. Brachiopoda (Revised), Volume 1. Geological Society of America \& University of Kansas Press, Boulder \& Lawrence.

Williams, A. \& MACKAY, S. 1979. Differentiation of the brachiopod periostracum. Palaeontology 22(3), 721-736.

WinRow, P. \& SutTon, M.D. 2012. Epithelian cell moulds in acrotretoid brachiopods. Historical Biology: An International Journal of Paleobiology 24(5), 557-565.

DOI 10.1080/08912963.2012.657633

Yao, H., DaO, M., Imholt, T., Huang, J., Wheeler, K., Bonilla, A., Suresh, S. \& Ortiz, C. 2010. Protection mechanism of the iron plated armor of a deep-sea hydrotermal vent gastropod. Proceedings of the National Academy of Sciences of the United States of America 107(3), 987-992.

DOI 10.1073/pnas.0912988107

Yoshioka, P.M. 1982. Predator-induced polymorphism in the bryozoan Mebranipora membranacea. Journal of Experimental Marine Biology and Ecology 61(3), 233-242.

DOI 10.1016/0022-0981(82)90071-5 